\title{
COMMENTS
}

\section{The Emerging Jurisprudence of Justice O'Connor}

\section{TABLE OF CONTENTS}

I. The Role of the Court . . . . . . . . . . . . . 392

A. "Traditional" Judicial Restraint. . . . . . . . . . . 394

1. Stare Decisis ....... . . . . . . . . . . . . . 394

New York v. Quarles

City of Akron v. Akron Center for Reproductive Health, Inc.

2. Statutory Construction ............. 403

Immigration \& Naturalization Service $v$. Phinpathya

Securities Industry Association v. Board of

Governors of the Federal Reserve

System

Bowsher v. Merck \& Co.

B. "Activist" Judicial Restraint ............... 408

1. Review of Agencies and Officials ........ 409

Allen v. Wright

Block v. Community Nutrition Institute

2. Review of Legislation ............... 417

ASARCO Inc. v. Idaho State Tax Commission

Zobel v. Williams

II. Federalism and the Court . . . . . . . . . . . . . . 423

A. Federal Legislation as a Limitation on State

Power

423

1. Tenth Amendment Limitations on Federal Power......................... 423

Federal Energy Regulatory Commission v.

Mississippi

Garcia v. San Antonio Metropolitan Transit Authority

2. Federal Preemption of State Legislation .... 428 
Southland Corp. v. Keating

Brown v. Hotel \& Restaurant Employees International Union Local 54

B. The Federal and State Judiciaries .......... 430

1. Exhaustion of State Remedies ......... 430

Rose v. Lundy

Engle v. Isaac

2. Adequate and Independent State Grounds. . 433 Michigan $v$. Long

III. The Calculus of Interests: Private Rights

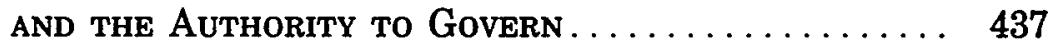

A. Deference to Government Interests: Criminal

Procedure...................... 438

1. Privacy Rights and Law Enforcement ..... 438 United States v. Place Hudson v. Palmer

2. Double Jeopardy ................... 443

Thigpen $v$. Roberts

Tibbs v. Florida

3. The Exclusionary Rule

Taylor v. Alabama

Immigration \& Naturalization Service v. Lopez-Mendoza

B. Limits on the Authority to Govern: The First Amendment and the Equal Protection Clause . . 448

1. First Amendment Rights... . . . . . . . . . . 449

Lynch v. Donnelly

Minneapolis Star \& Tribune Co. v. Minnesota Commissioner of Revenue

Brown v. Socialist Workers '74 Campaign Committee

Roberts $v$. United States Jaycees

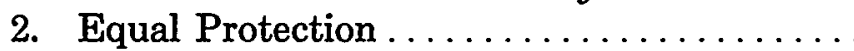

Mississippi University for Women v. Hogan 


\section{The Emerging Jurisprudence of Justice O’Connor}

The appointment of Sandra Day O'Connor to the United States Supreme Court in 1981 generated unusually widespread interest and provoked much speculation about the probable direction of her jurisprudence. Justice O'Connor came to the Court with considerable experience in the three branches of Arizona state government-as assistant attorney general, as senate majority leader, and as both trial and appellate judge. Much speculation focused on the influence that this experience might have on her approach to federal statutory and constitutional law.

There was also considerable anticipation about the impact that President Reagan's first appointee might have in shifting the Court in a more "conservative" direction. But judicial conservatism is an ambiguous concept, which may imply an emphasis on reaching certain substantive results or an emphasis on a restrained procedural approach to deciding cases. A question inevitably arises about how far a "conservative" Justice may be willing or able to alter trends in constitutional jurisprudence.

At this time, with Justice O'Connor having completed three terms on the Court, it is appropriate to consider her emerging jurisprudence. This comment presents an analysis of the Justice's written opinions-majority, concurring, and dissenting-during her brief tenure on the Court. ${ }^{3}$ By identifying and explaining the recurring themes in her judicial approach, the comment offers some suggestions about the mark she has made and will continue to make on the Court.

Part I considers Justice O'Connor's approach to the institutional role of the Supreme Court. Although this subject might have an insignificant place in an analysis of the work of many judges, it

1 For a statistical tabulation of Justice O'Connor's voting record on the Court, see each year's November issue of the Harvard Law Review. The Supreme Court, 1983 Term, 98 Hanv. L. REv. 1, 307-10 (1984); The Supreme Court, 1982 Term, 97 HaRv L. Rev. 1, 295-98 (1983); The Supreme Court, 1981 Term, 96 HARv. L. Rev. 1, 304-07 (1982). Analysis of a Justice's voting record, which concentrates on the results reached in cases, is certainly informative, but its usefulness is limited. For example, a bare statistical analysis offers little insight into the substance of Justice O'Connor's jurisprudence-that is, the reasoning that she uses to reach and explain her votes. This comment examines her jurisprudence rather than the Justice herself. That is, it does not attempt to explain her positions in terms of her "preferences," be they real or supposed. Instead, it focuses on the opinions that she has produced in her first three terms in order to suggest how their general themes might affect the Court's jurisprudence. 
is worth examining carefully in this instance. Justice O'Connor urges a more restrained role for the Court, and the central theme of this discussion is her concern with limiting the judiciary's interference with the functioning of the coordinate branches of the federal government.

Part II examines the Justice's views on federalism, an issue that caused great difficulty at the Constitutional Convention and about which there has never been a satisfactory consensus. Justice O'Connor's efforts in this area are marked by an attempt to erect defensive protections for state governmental functions.

Part III focuses on Justice O'Connor's view of constitutional protections extended to individuals. Justice O'Connor's approach here mirrors the themes that emerge in the first two parts: again, she seeks to protect government purposes and operations-especially those of the states-against extensive regulation by the courts. In assessing the balance between individual rights and government interests, she displays a special solicitude for the latter.

\section{The Role of the Court}

When a case arrives before the Supreme Court, each Justice must consider two very different kinds of issues. Each case raises substantive legal questions. But these substantive legal questions are immersed in a particular procedural history. The tendency of a Justice to emphasize more frequently one or the other of these aspects of a case may reflect that Justice's views about the role of the Court. By emphasizing substantive legal questions over procedural factors, a Justice may manifest an aggressive desire for the Court to express judgments on the substantive legal questions involved. When a Justice emphasizes the procedural setting of a case, however, particular substantive results may become less important. Such an approach reflects a conviction that legal questions should be resolved by the Court only when necessary. ${ }^{2}$

Justice O'Connor often attacks the issues in a case by attending closely to its particular procedural history. ${ }^{3}$ Her approaches to

2 Nevertheless, procedural concerns can also be invoked as a veneer to mask a Justice's particular substantive positions and can be used to reach the desired result without having to defend the substantive position. Thus, in inferring a Justice's views on the role of the Court from that Justice's statements about procedural concerns, it is important that the underlying substantive context of the particular case be examined.

${ }^{3}$ See, e.g., Firefighters Local Union No. 1784 v. Stotts, 104 S. Ct. 2576, 2591 (1984) (O'Connor, J., concurring) (reviewing the "complete procedural perspective" of the case in order to clarify the Court's decision); Director, Office of Workers' Compensation Programs v. Perini N. River Assocs., 459 U.S. 297, 302 (1983) (O'Connor, J.) (rejecting an argument 
stare decisis and statutory construction also reflect some adherence to traditional limitations on judicial conduct. Nonetheless, a closer examination of these two issues raises questions about how consistently Justice O'Connor adheres to this position and how much she actually differs in this respect from other Justices.

Moreover, Justice O'Connor sometimes goes beyond traditional constraints. Her attention to the procedural posture of a case is not limited to its legal context; she also pays close attention to its political context, or its "posture" within the constitutional system. She is especially careful, in examining a case, to note the pertinent responsibilities of officials in other branches and levels of government. She then draws inferences from those responsibilities that limit the scope of judicial power. ${ }^{4}$ This approach transcends traditional judicial restraint: not only should the Court avoid ruling on substantive legal issues where possible, but the Court should also interpret these issues, and the Constitution itself, so as to limit judicial intrusions upon the coordinate branches of government. This position denies that the Court's role should be shaped merely by its responsibility to protect individual rights. Instead, the Court must also respect the democratic exercise of the power to govern. According to this view, that power is reposed primarily in the politically responsible branches of government and must not be unduly hindered by the aggressive exercise of judicial power. ${ }^{5}$

Justice O'Connor's approach takes shape as an interesting and sometimes paradoxical blend of statements that support both ordinary judicial restraint and attempts to set out more radical limitations on the judicial role. Indeed, at times she takes "activist" posi-

about standing that "ignores the procedural posture" of the case).

4 A good example of this approach is Board of Educ. v. Pico, 457 U.S. 853, 921 (1982) ( $O$ 'Connor, J., dissenting), where she rejected a first amendment challenge to a school board's removal of nine books from its curriculum and its libraries by emphasizing the broad scope of the board's responsibilities.

- Consider the following statement by Justice Douglas on this controversy:

There has long been a school of thought here that the less the judiciary does, the better. It is often said that judicial intrusion should be infrequent, since it is "always attended with a serious evil, namely, that the correction of legislative mistakes comes from the outside, and the people thus lose the political experience, and the moral education and stimulus that come from fighting the question out in the ordinary way, and correcting their own errors."

Flast v. Cohen, 392 U.S. 83, 110 (1968) (Douglas, J., concurring) (quoting JAMEs ThaYer, John Marshall 106 (1901)). Justice Douglas then stated his opposing view, emphasizing that the federal judiciary is designed to play an important role in "guarding basic rights against majoritarian control," often as "the one and only place where effective relief can be obtained." 392 U.S. at 110-11. For further discussion of the tension between individual rights and a majoritarian view of government, see infra text following note 207. 
tions in order to limit the scope of judicial power over the rest of the government. These two aspects of her position will be considered in turn.

\section{A. "Traditional" Judicial Restraint}

Restraint is a common theme in Justice O'Connor's statements about the judicial role. She often writes pointed concurring opinions that narrow the Court's holding. ${ }^{6}$ She protests when the Court resolves issues that she thinks are not properly before it ${ }^{7}$ and when the Court reaches issues that are not necessary, in her view, to dispose of the case. ${ }^{8}$ Moreover, she emphasizes that courtroom confrontations are not the sole way, and often not the best way, to resolve disputes. ${ }^{\circ}$ Other aspects of her jurisprudence, however, are more telling about the precise contours of her view of judicial restraint.

1. Stare Decisis. A significant illustration of Justice O'Connor's views on judicial restraint is her approach to the principle of stare decisis. She sometimes expresses reluctance to disturb prior decisions with which she disagrees, especially where ordinary practice has conformed to those pronouncements. ${ }^{10}$ Nonetheless, this reluctance typically does not prevent her from

' See, e.g., California v. Trombetta, 104 S. Ct. 2528, 2536 (1984) (O’Connor, J., concurring) (summarizing the Court's holding as comprising only three "well-settled propositions"); Globe Newspaper Co. v. Superior Court, 457 U.S. 596, 611 (1982) (O'Connor, J., concurring) (agreeing that the first amendment protects the right of press and public to attend criminal trials, but rejecting any broader implications outside that context).

'See, e.g., Philko Aviation, Inc. v. Shacket, 462 U.S. 406, 414-15 (1983) (O'Connor, J., concurring) (joining the Court's opinion except insofar as it suggested a resolution of an issue not presented to it); North Dakota v. United States, 460 U.S. 300, 323 (1983) ( $O^{\prime}$ Connor, J., concurring) (criticizing the Court for deciding an issue not properly before it and not raised in the court below).

${ }^{8}$ See, e.g., Edgar v. MITE Corp., 457 U.S. 624, 655 (1982) (O’Connor, J., concurring in part) (agreeing with the Court's decision, but not joining its resolution of an issue that she thought was unnecessary to that decision).

- For example, she showed a strong preference for the voluntary settlement of disputes in Firefighters Local Union No. 1784 v. Stotts, 104 S. Ct. 2576, 2593-94 (1984) (O'Connor, J., concurring) (involving a voluntary consent decree in a Title VII action), and in Schaefer v. NLRB, 104 S. Ct. 362, 364 (1983) (O'Connor, J., dissenting from denial of certiorari) (seeking to clarify NLRB policy that defers to private resolutions of labor disputes).

${ }^{10}$ See, e.g., Guardians Ass'n v. Civil Serv. Comm'n, 103 S. Ct. 3221, 3237-38 (1983) (O'Connor, J., concurring) (construing Title VI to redress nothing more than purposeful discrimination, but stating that she might have construed the statute differently had the Court not already ruled on the issue in Regents of the Univ. of Cal. v. Bakke, 438 U.S. 265 (1978)); cf. Paisy v. Board of Regents, 457 U.S. 496, 517 (1982) (O'Connor, J., concurring) (agreeing "reluctantly" that exhaustion of state administrative remedies is not a prerequisite to an action under section 1983, thus standing behind the Court's settled interpretation of congressional intent even against what she considered to be sound policy). 
reaching substantive issues. A prominent example is her opinion in New York v. Quarles. ${ }^{11}$

Benjamin Quarles was charged with criminal possession of a weapon. Police had apprehended him in a supermarket because he matched the description of a suspected rapist. In frisking him, the police discovered an empty shoulder holster. Before giving $\mathrm{Mi}$ randa warnings to the suspect, the police asked him where the gun was. Quarles told them and they found the gun. The police then read Quarles his Miranda rights before questioning him further. The lower court ruled that neither Quarles' first statement nor the gun was admissible as evidence because Miranda warnings had not been given.

The Supreme Court reversed. Justice Rehnquist, writing for a bare majority, set out a "public safety exception" to the requirement that Miranda warnings be given before a suspect's statements may be admitted as evidence. The police face many situations where prompt and effective action must be taken to counter serious threats to public safety, and the Court held that Miranda warnings are dispensable until those threats are extinguished. ${ }^{\mathbf{1 2}}$

Justice Rehnquist frankly acknowledged the issue of stare decisis. He argued that the holding in Miranda $v$. Arizona ${ }^{13}$ was limited primarily to a concern for the suspect's fifth amendment privilege against self-incrimination "in the presumptively coercive environment of the station house."14 Yet he admitted that the Court had not specifically limited the Miranda rule to stationhouse questioning. ${ }^{15}$ Justice Rehnquist also recognized that the Court's ruling would lessen the clarity of the Miranda rule. Nonetheless, he argued that this exception would not require an "onthe-scene balancing process" and could be applied "almost instinctively" by police officers. ${ }^{18}$

Justice O'Connor concurred in part and dissented in part. Although she sympathized with the substance of the Court's holding, she emphatically disagreed with the majority's formal approach:

[T]he Court acknowledges that it is departing from prior precedent . . . and that it is "lessen[ing] the desirable clarity of [the Miranda] rule" ... Were the Court writing from a

\footnotetext{
11104 S. Ct. 2626 (1984).

1s Id. at $2632-33$.

13384 U.S. 436 (1966).

14104 S. Ct. at 2632 (citing Miranda, 384 U.S. at 455-58).

Is See $104 \mathrm{~S}$. Ct. at 2631 n.4 (citing cases).

16 Id. at 2633 .
} 
clean slate, I could agree with its holding. But Miranda is now the law and, in my view, the Court has not provided sufficient justification for departing from it or for blurring its now clear strictures. $^{17}$

In assessing the Court's many pronouncements on the Miranda rule, Justice O'Connor stressed its durability and clarity. ${ }^{18}$ The balance between individual rights and effective law enforcement is inevitably precarious, and a kind of equilibrium had been achieved following Miranda. The burden of securing public safety without infringing Miranda rights had been squarely placed upon the state government, and law enforcement officials had adjusted to the rule. Thus, she found no justification for the Court to upset this "equilibrium" for "a fine-spun new doctrine on public safety exigencies incident to custodial interrogation, complete with the hair-splitting distinctions that currently plague our Fourth Amendment jurisprudence."19 For example, after Quarles there could be substantial dispute over the meaning of "public safety."

Nonetheless, Justice O'Connor agreed with the Court's substantive attempt to limit the scope of Miranda. Indeed, she went further. Her approach would have softened the state's prosecutorial burden by distinguishing testimonial evidence from non-testimonial evidence and admitting at trial the non-testimonial fruits of a Miranda violation. ${ }^{20}$ Hence, in Quarles she would have excluded the initial statement but allowed the gun as evidence. Ironically, this proposal led Justice Marshall to criticize her for the same fault she had found with Justice Rehnquist: departure from precedent. Justice Marshall's dissent pointed to a line of cases that support a "fruit of the poisonous tree" doctrine, which would exclude incriminating evidence, particularly physical eviomitted).

${ }^{17} \mathrm{Id}$. at 2634 (O'Connor, J., concurring in part and dissenting in part) (citations

${ }^{18}$ This emphasis on the need for the Court to provide clear rules is a recurrent theme in Justice O'Connor's opinions. See, e.g., Michigan v. Long, 103 S. Ct. 3469, 3474-76 (1983) (offering clearer guidance on when the Supreme Court will not review a state court decision because it rests on an "adequate and independent state ground"); City of Akron v. Akron Center for Reproductive Health, Inc., 462 U.S. 416, 454 (1983) (O'Connor, J., dissenting) (suggesting a new approach to reviewing abortion laws, which would replace the Court's increasingly blurry trimester framework); see also cases cited infra note 49.

$19104 \mathrm{~S}$. Ct. at 2636 (O'Connor, J., concurring in part and dissenting in part).

${ }^{20} \mathrm{Id}$. at 2634, 2637-41. Justice O'Connor's position here is consistent with her general approach to resolving the balance between individual rights and state interests. For a more detailed consideration of her views on the exclusionary rule, see infra notes 242-56 and accompanying text. 
dence, that was illegally obtained. ${ }^{21}$

Justice Marshall's criticism and Justice O'Connor's response ${ }^{22}$ help clarify her position on stare decisis. There is a crucial difference between Justice Rehnquist's approach in Quarles and her own. Justice Rehnquist openly deviated from precedent in order to erect an exception to the established Miranda rule. Justice O'Connor, however, found a gap between competing lines of precedent. Against the doctrine noted by Justice Marshall, she cited another quite different line of cases, beginning with Schmerber $v$. California. ${ }^{23}$ In these cases, the Court had refused to use the fifth amendment privilege against self-incrimination to suppress nontestimonial evidence obtained outside the courtroom. ${ }^{24}$ She then pointed to Michigan $v$. Tucker ${ }^{25}$ to show that the Court had left open the question of whether physical evidence obtained in violation of Miranda would be admissible. Finally, she argued that the "fruit of the poisonous tree" doctrine had been limited in application to infringements of "core" constitutional rights that safeguard the adversary system of justice, not to the prophylactic Miranda standards. ${ }^{26}$

Justice O'Connor's approach, characterized by Justice Marshall as a "radical departure from precedent," can be reconciled

21104 S. Ct. at 2649-50 \& n.11 (Marshall, J., dissenting). An early statement of this view was given by Justice Holmes in a fourth amendment case. See Silverthorne Lumber Co. v. United States, 251 U.S. 385, 391-92 (1920). Justice Marshall also cited Nix v. Williams, $104 \mathrm{~S}$. Ct. 2501 (1984), to show that the rule had been expanded to cover violations of the fifth and sixth amendments.

$22104 \mathrm{~S}$. Ct. at 2640 n.4 (O'Connor, J., concurring in part and dissenting in part). In connection with this discussion, note Justice Marshall's brief criticism of Justice O'Connor for deciding an issue not properly before the Court, id. at 2649 n.11 (Marshall, J., dissenting), and her brief discussion of that same issue, id. at $2637 \mathrm{n} .2$ (O'Connor, J., concurring in part and dissenting in part).

${ }^{23} 384$ U.S. 757 (1966) (decided one week after Miranda). For a discussion of these cases, see Quarles, 104 S. Ct. at 2637-39 (O'Connor, J., concurring in part and dissenting in part).

24 See, e.g., Gilbert v. California, 388 U.S. 263, 265-66 (1967) (accused required to provide handwriting sample); United States v. Wade, 388 U.S. 218, 221-23 (1967) (accused required to stand in a lineup and speak on cue).

2s 417 U.S. 433, 445-46 (1974) (involving the use of testimony of witness discovered by police as a result of statement by defendant). Tucker involved facts arising before Miranda was decided, but the Court's ruling was said to be consistent with the exclusionary rule as applied to Miranda violations. Id. at 444-46.

28 $104 \mathrm{~S}$. Ct. at 2640 n.4 (O'Connor, J., concurring in part and dissenting in part). Thus, Justice O'Connor distinguished between a situation, as in Quarles, where the police merely failed to give Miranda warnings, and situations where a suspect had been compelled to speak by abusive police practices. In the latter circumstances, she would apply the broader exclusionary rule. Id. at 2639-40.

${ }^{27}$ Id. at 2649 n.11 (Marshall, J., dissenting). 
with adherence to stare decisis, at least on the surface. In this instance, the precedents could be regarded as conflicting. She identified one developing body of doctrine and took up its cause against a more entrenched but antithetical body of doctrine. To do so is an inevitable part of the judicial function, understood as a process that moves in fits and starts to clarify the content and extent of guiding legal principles. ${ }^{28}$ Although one might reject the analogy she made to this differing line of precedent, her approach does differ from creating a new and uncertain exception to a clear and durable rule, which she refused to do without "a clean slate."28

The importance of Justice O'Connor's opinion in Quarles is her refusal to overturn a precedent with which she disagreed. The nature of Justice O'Connor's restraint is ambiguous here, however, because she was able to reach a similar substantive result in her concurrence. Although less testimonial evidence would be admissible under her approach than under the Court's approach, much more non-testimonial evidence would be admissible at trial, thus limiting the bite of the exclusionary rule. Her notion of restraint in Quarles was compatible with change; its effect was not so much on the result as on how the result was achieved. Yet, because she achieved part of the desired result by another avenue, her invocation of stare decisis was perhaps of less significance.

In Quarles, Justice O'Connor did not find "sufficient justification" to depart from the principle of stare decisis. ${ }^{30}$ She offered some guidance as to what constitutes "sufficient justification" in her vigorous dissent in City of Akron v. Akron Center for Reproductive Health, Inc., ${ }^{31}$ one of three companion cases in which the Court reviewed state and local abortion regulations. ${ }^{32}$ The Court

28 Justice O'Connor's use of Schmerber and its progeny is an attempt to bring together different but possibly analogous lines of precedent. As Judge Cardozo noted: "Rules appropriate to spheres which are conceived of as separate and distinct cannot both be enforced when the spheres become concentric. There must then be readjustment or collision." Hynes v. New York Cent. R.R., 231 N.Y. 229, 236, 131 N.E. 898, 900 (1921). The question raised by this attempt is whether the analogy she offered between these two lines of precedent is persuasive. For a discussion of this understanding of judicial practice, see generally EDWARD LeVi, An Introduction to Legal Reasoning passim (1949).

${ }^{29} 104 \mathrm{~S}$. Ct. at 2634 (O'Connor, J., concurring in part and dissenting in part). Justice O'Connor made a similar attempt to apply one line of cases to a situation in which they had previously been thought inapposite in United States v. Place, 103 S. Ct. 2637 (1983) (extending rationale for permissible search without probable cause to seizure of property without probable cause); see infra notes 211-25 and accompanying text.

so $104 \mathrm{~S}$. Ct. at 2634 (O'Connor, J., concurring in part and dissenting in part).

s1 462 U.S. 416 (1983).

s2 The other cases were Simopoulos v. Virginia, 462 U.S. 506 (1983), and Planned Parenthood Ass'n v. Ashcroft, 462 U.S. 476 (1983). 
expressly reaffirmed its ten-year-old decision in Roe $v$. Wade, ${ }^{33}$ which established a trimester analysis for determining the permissible scope of abortion laws. This analysis provided, in part, that a woman's right to privacy encompasses the right to decide whether or not to terminate her pregnancy during the first trimester and that the state may not prescribe regulations that impose any significant burden on a woman's exercise of her right during that period. Applying this standard in Akron, the Court invalidated the particular ordinance at issue. ${ }^{34}$

Although agreeing with the Court that stare decisis is one of the most fundamental judicial principles, Justice O'Connor pointed to past decisions that applied the principle less rigidly in constitutional cases, especially when the Court was "convinced of former error." 35 She urged the Court to take a sweeping step and reject the trimester analysis established in Roe because, in her view, it "is a completely unworkable method of accommodating the conflicting personal rights and compelling state interests that are involved in the abortion context." 36 She especially disagreed with the broad scope of a woman's privacy right during the first trimester.

Justice O'Connor presented two different kinds of arguments against the Court's approach to the abortion issue. In her first attack, she argued that Roe itself had been wrongly decided: the imposition of the trimester framework was based on an underestimation of the state interests involved. One of the postulates of Roe was that although the state has a legitimate interest in potential life, this interest becomes compelling only after the fetus reaches viability. Once this point has been reached, the state's compelling interest will support even a total ban on abortions. ${ }^{37}$ Justice

3s 410 U.S. 113 (1973); see Akron, 462 U.S. at 420 \& n.1.

34462 U.S. at 452.

${ }^{38}$ Id. at 458-59 (O'Connor, J., dissenting) (quoting Smith v. Allwright, 321 U.S. 649, 665 (1944)); cf. Gideon v. Wainwright, 372 U.S. 335, 346 (1963) (Douglas, J., concurring) ("all constitutional questions are always open"); Graves v. New York ex rel. O'Keefe, 306 U.S. 466, 491-92 (1939) (Frankfurter, J., concurring) (principle of stare decisis is more limited in constitutional cases because "[t]he ultimate touchstone of constitutionality is the Constitution itself, and not what we have said about it").

36 462 U.S. at 454 (O'Connor, J., dissenting).

${ }^{37}$ Roe, 410 U.S. at 163-64. Justice O'Connor also criticized Roe's holding that the state's interest in maternal health becomes compelling only after the first trimester. As with the state's interest in potential life, she argued that this interest is compelling throughout the pregnancy. Akron, 462 U.S. at 460 (O'Connor, J., dissenting). Although acceptance of this proposition would make serious inroads on the constitutional right created by Roe, it would not necessarily justify a total ban on abortions: Roe had held that the state's compelling interest in maternal health only justifies the regulation of abortions. Roe, 410 U.S. at 
O'Connor criticized the "viability" line as artificial. There was no real justification for concluding that a state's interest in protecting potential human life becomes compelling only at viability: "At any stage in pregnancy, there is the potential for human life." ${ }^{38} \mathrm{Com}$ bined with Roe's holding that the state's compelling interest in potential life would allow a state to prohibit all abortions, this would lay the groundwork for a complete evisceration of the restraints that Roe placed upon the states.

Justice O'Connor's other argument for rejecting Roe was that, quite apart from whether Roe was wrongly decided, its trimester approach to abortion cases had become indefensible and unworkable. This conclusion was based on three major criticisms. First, the trimester lines had become blurred by advances in medical technology. Those lines were drawn according to the state of medical practice in 1973. As medical practice has evolved, and continues to evolve, the underlying justifications for the trimester lines are steadily weakened. The trimester framework provided a clear rule, but it had become divorced from its rationale: the clear rule was no longer defensible. As she pointed out, the Court in Akron was willing to depart from the clear trimester lines in order to remain consistent with current medical practice. ${ }^{38}$ Thus, the trimester approach no longer provided state and local lawmakers with clear guidance separating permissible from impermissible regulation. ${ }^{40}$

Second, the trimester framework required the judiciary to engage in a task for which it is not competent. Roe required courts to function as "the Nation's 'ex officio medical board," "41 constantly revising putative constitutional standards to keep pace with changes in medical practice. If such determinations could be made at all, they could be made more capably by the legislative branch of government. ${ }^{42}$

Finally, Justice O'Connor argued that the Roe framework was inherently self-destructive:

Just as improvements in medical technology inevitably

163.

${ }^{38} 462$ U.S. at 461 (O'Connor, J., dissenting) (emphasis in original).

${ }^{38}$ Id. at $454-55 \& \mathrm{n} .2$ (citing id. at $431,435-36$ ).

${ }^{10} I d$. at 455 (O'Connor, J., dissenting).

12 Id. at 456 (quoting Planned Parenthood v. Danforth, 428 U.S. 52, 99 (1976) (White, J., concurring in part and dissenting in part)).

42462 U.S. at 456 n.4 (O’Connor, J., dissenting). Justice O'Connor's statement here reflects her narrow view of the judicial function in relation to other branches of government. For a general discussion of this subject, see infra notes 51-137 and accompanying text. 
will move forward the point at which the State may regulate for reasons of maternal health, different technological improvements will move backward the point of viability at which the State may proscribe abortions except when necessary to preserve the life and health of the mother. ${ }^{43}$

Many abortion regulations can be viewed as involving both of these somewhat overlapping concerns: protection of maternal health and protection of potential life. Thus, Justice O'Connor argued, the very same abortion regulations may become more justifiable from the standpoint of protecting potential life even as they become less justifiable from the standpoint of protecting maternal health. These contradictory trends will inevitably add further confusion to determinations on this issue. ${ }^{44}$

In rejecting both the rationale of $R o e$ and its trimester analysis, Justice O'Connor offered a different approach to the abortion cases. Stressing the limited nature of the privacy right involved, which "cannot be said to be absolute," "45 she argued from prior cases that this right merely protects a woman from an "unduly burdensome" interference with her decision about whether or not to terminate pregnancy. ${ }^{46}$ Thus, setting aside any divisions of pregnancy by trimester, she offered the following alternative to the Roe framework: any regulation not imposing an undue burden on a woman's right to decide whether to have an abortion would require minimal judicial scrutiny; an unduly burdensome regulation could be upheld as justified, but only on a showing of a compelling state interest. ${ }^{47}$ Given Justice O'Connor's willingness to extend the reach of the state's compelling interests, this test would permit much broader interference by the state with a woman's abortion decision.

43462 U.S. at $456-57$ (O'Connor, J., dissenting) (emphasis in original).

"It is not clear just what to make of this argument. No necessary contradiction arises from these opposing trends; they merely suggest that over time states will become less free to regulate abortions for purposes of maternal health even as they become more free to proscribe abortions altogether. So long as these justifications can be separated from one another-that is, so long as proscription can be separated from mere regulation-these trends do not represent a "collision course." Yet, to the extent that it is hard to separate these justifications when examining particular regulations (e.g., regulations of maternal health that amount to proscriptions or near-proscriptions), the opposing trends may help to create additional confusion.

45462 U.S. at 463 (O'Connor, J., dissenting) (quoting Roe, 410 U.S. at 154).

48 See 462 U.S. at 461-65 \& n.8 (O'Connor, J., dissenting). She equated the phrase "unduly burdensome" with "situations involving absolute obstacles or severe limitations on the abortion decision." Id. at 464. She also favored significant but not complete deference to legislative judgments about what would constitute an "undue burden." Id. at 461 \& n.10.

47 Id. at 461-65. 
Thus, Justice O'Connor was willing to depart from stare decisis under the circumstances that she found to be present in Akron: when the underlying precedent offered blurred guidance, when it cast the judiciary in an inappropriate role, and when it contained underlying analyses pointing in opposite directions. Even here, however, she seemed to act out of concern for judicial restraint by asking the Court to retreat from what she considered to be unduly obtrusive activity under Roe. One of the primary defects of Roe, in her view, is that it makes necessary constant revisions by the Court of its own unjustified scientific and policy judgments. Thus, her Akron dissent may exemplify her willingness to be "activist" in defense of judicial restraint.

Like Quarles, however, Akron offers ambiguous guidance about the contours of Justice O'Connor's notion of restraint. On the one hand, Akron might indicate the extreme set of circumstances that must be present before she is willing to depart from precedent. This would be consistent with her statement that departure from stare decisis is an "exceptional action" demanding "special justification" even in constitutional cases. ${ }^{48}$ As her opinion in Quarles suggests, the principle of stare decisis should outweigh a Justice's own view that a prior decision is merely wrong, or even very wrong; but the additional problems surrounding the Roe decision are enough to justify departure from stare decisis. On the other hand, Akron may simply show her rejecting a case that she thought was wrongly decided in order to reach a more desirable substantive result. Although she presented a variety of arguments for overturning Roe, it is not entirely clear how important or necessary each of those justifications was in leading her to that outcome. Thus, although Quarles shows Justice O'Connor's concern for adhering faithfully even to a disagreeable precedent, Akron suggests that she does not consider such fidelity to be the fundamental guiding principle of her jurisprudence. ${ }^{40}$

18 Arizona v. Rumsey, 104 S. Ct. 2305, 2311 (1984) (O'Connor, J.).

19 Other instances where Justice $O^{\prime}$ Connor evinced less concern for ordinary aspects of judicial restraint include United States v. Place, $103 \mathrm{~S}$. Ct. 2637, 2644-45 (1983) (stating, in dicta, that "sniff tests" by dogs trained to locate narcotics are not searches within the meaning of the fourth amendment), and Garcia v. San Antonio Metro. Transit Auth., $105 \mathrm{~S}$. Ct. 1005, 1038 (1985) (O'Connor, J., dissenting) (agreeing with Justice Rehnquist's prediction, $i d$. at 1033 (Rehnquist, J., dissenting), that the Court's decision to overrule its own tenth amendment doctrine will itself be overruled in time).

Justice O'Connor's position on judicial restraint aside, she quite clearly expects the Supreme Court to exercise strong guiding power within the judicial system. She feels that restraint must not lead the Court to abdicate its responsibilities as the supreme judicial authority. Thus, one of her major themes is clarity; she often writes brief concurrences to 
2. Statutory Construction. In keeping with her views about the limits of judicial authority, Justice O'Connor attempts to limit judicial involvement in the task of legislation. Congress is the lawmaking body, and she generally seeks to construe statutes in a way that narrows the range of judicial discretion. Yet the task of statutory construction presents a peculiar imbroglio of legislative and judicial powers that has long obscured the neat partitions in the constitutional system, leading both to the confusing and contradictory welter of judicial "rules" for statutory construction ${ }^{50}$ and to frequent criticism of the judiciary for usurping the legislative power. Justice O'Connor, like most other judges, has had difficulty here.

When Justice O'Connor examines statutory language, she typically finds guidance in the general rules that the analysis "must begin with the language of the statute itself," " and that "[a]bsent a clearly expressed legislative intention to the contrary, that language must ordinarily be regarded as conclusive." "51 For example, she adopted the "plain meaning" approach to statutory interpretation, with a harsh result, in Immigration \& Naturalization Service v. Phinpathya. ${ }^{52} \mathrm{~A}$ Thai woman and her husband had remained in the United States illegally after their visas had expired. In all, they had resided here for more than seven years. The Immigration and Naturalization Service (INS) began deportation proceedings against the couple, who conceded that they were deportable aliens but applied to an immigration judge for suspension of the proceed-

clarify the Court's holding. See, e.g., California v. Trombetta, 104 S. Ct. 2528, 2535-36 (1984) (O'Connor, J., concurring) (summarizing the Court's opinion as comprising only three "well-settled" propositions); United States v. Doe, 104 S. Ct. 1237, 1245 (1984) (O'Connor, J., concurring) (emphasizing a point that was "implicit" in the Court's analysis); cf. Zobel v. Williams, 457 U.S. 55, 73 (1982) (O'Connor, J., concurring) (criticizing the Court for establishing "an uncertain jurisprudence" in the equal protection area). At times, she has gone further and offered explicit instruction to a lower court on remand. See General Bldg. Contractors Ass'n v. Pennsylvania, 458 U.S. 375, 403-05 (1982) (O'Connor, J., concurring) (stating one of the options open to the district court on remand); Boag v. MacDougall, 454 U.S. 364, 366 (1982) (O'Connor, J., concurring) (same). She also has not hesitated to assert the Court's responsibility to review the findings of fact made by special masters in cases falling under the original jurisdiction of the Court. See Colorado v. New Mexico, 104 S. Ct. 2433, 2439 (1984); Idaho ex rel. Evans v. Oregon, 103 S. Ct. 2817, 2828-29 (1983) (O’Connor, J., dissenting).

so See Karl Llewellyn, The Common law Tradition: Deciding Appeals 521-35 (1960).

s1 Bread Political Action Comm. v. Federal Election Comm'n, 455 U.S. 577, 580 (1982) (quoting Dawson Chem. Co. v. Rohm \& Haas Co., 448 U.S. 176, 187 (1980); Consumer Prod. Safety Comm'n v. GTE Sylvania, Inc., 447 U.S. 102, 108 (1980)); see also Immigration \& Naturalization Serv. v. Phinpathya, 104 S. Ct. 584, 589 (1984) (quoting Bread, 455 U.S. at 580); FBI v. Abramson, 456 U.S. 6I5, 635 (1982) (O'Connor, J., dissenting) (same).

B3 104 S. Ct. 584 (1984). 
ings pursuant to statute. The statute allowed the proceedings to be suspended when an alien, among other things, "has been physically present in the United States for a continuous period of not less than seven years." husband, but found that the wife did not satisfy the requirement of "continuous" presence, since she had left the country for three months during the seven-year period.

Justice O'Connor's opinion for the Court agreed with the immigration judge. She understood the statute, according to its ordinary meaning, to require seven years of continuous physical presence, with no exceptions. ${ }^{54}$ She argued that the legislative history supported this strict reading and refused to adopt a more liberal construction: "Congress designs the immigration laws, and it is up to Congress to temper the laws' rigidity if it so desires."

In his concurring opinion, Justice Brennan argued that this interpretation was too harsh. In his view, the Court should apply general terms so as to avoid "injustice, oppression, or an absurd consequence. It will always, therefore, be presumed that the legislature intended exceptions to its language, which would avoid results of this character. The reason of law in such cases should prevail over its letter." "Js Justice Brennan feared that the Court's reading would allow "continuous" physical presence for seven years to be negated, for example, by a short vacation to Mexico or an inadvertent train ride through Canada while going from Buffalo to Detroit. $^{.7}$

Justice O'Connor's dissent in Securities Industry Association $v$. Board of Governors of the Federal Reserve System ${ }^{58}$ helps to explain her concern about statutory interpretation based on policy judgments or judgments grounded on the spirit of the law. Briefly stated, the statutory question was whether commercial paper was a "security" under the Glass-Steagall Act. ${ }^{5}$ The Court held that it was; ${ }^{60}$ Justice O'Connor concluded that the Board of Governors of

s3 8 U.S.C. § 1254(a)(1) (1982).

s4 104 S. Ct. at 589.

so Id. at 592-93.

sB Id. at 594 (Brennan, J., concurring) (quoting United States v. Kirby, 74 U.S. (7 Wall.) $482,486-87$ (1868)).

${ }^{57} 104$ S. Ct. at 593 (Brennan, J., concurring). Justice Brennan also disagreed with the Court's reading of the legislative history. He concurred in the judgment, however, because he agreed that an unexplained three-month absence from the country was enough to disqualify an alien from relief from deportation. $I d$.

ss 104 S. Ct. 2979 (1984).

Bo Banking Act of 1933, $\S 16,21,12$ U.S.C. $\$ \S 24,378(a)(1)(1982)$.

Bo 104 S. Ct. at 2981. 
the Federal Reserve System had not unreasonably decided that it was not. ${ }^{61}$ The brunt of her disagreement centered on the Court's preoccupation with the policies of the Act:

The dangers that Congress sought to eliminate when it enacted the Glass-Steagall Act are easily stated at a level of generality that might make the Board's ruling appear inconsistent with congressional policies. The translation of policy into legislation, however, is always complicated by the necessity of taking into account potentially competing and overlapping laws and policies. The task of this Court, therefore, is to interpret the statutory language that Congress enacted into law. ${ }^{62}$

This statement suggests a view that laws are the outcome of a struggle among interests within the legislative process. That process domesticates the competing interests through compromise. Laws emerge in their particular shape because they are molded by that particular process. Thus, the general principles that are articulated in those struggles are less trustworthy as a guide to legislation than the actual words of statutes, which were, in the end, all that Congress passed. As a result, the Court must not substitute itself for Congress by unnecessarily interpreting a statute according to its putative underlying policies. As Justice O'Connor stated in another case, "It is not the function of this Court . . . to apply the finishing touches needed to perfect legislation. Our job does not extend beyond attempting to fathom what it is that Congress produced, blemished as the Court may perceive that creation to be." ${ }^{\text {3 }}$ In other words, the Court has some latitude to interpret statutory language that makes no logical sense. But the Court has no latitude to interpret statutory language that makes no policy sense. ${ }^{64}$

1. Id. at 3003 (O'Connor, J., dissenting).

62 Id. She combined the themes of judicial deference to administrative agencies and to Congress in her strongly worded conclusion: "It is singularly inappropriate for this Court, reasoning from the general policies it finds in the statute and with little regard for the statutory language, to reject the construction of the statute adopted by the Board after careful consideration and with full explanation." Id.; cf. Arizona Governing Comm. v. Norris, $103 \mathrm{~S}$. Ct. 3492, 3511 (1983) (O'Connor, J., concurring) ("[O]ur judicial role is simply to discern [congressional] intent. . . . What we, if sitting as legislators, might consider wise legislative policy is irrelevant to our task.").

es FBI v. Abramson, 456 U.S. 615, 644 (1982) (O’Connor, J., dissenting).

6r Id. at $634,641-44 \&$ n.12. This distinction between logical sense and policy sense seems difficult to draw, however, in any of the hard cases where one can conceive of "absurd consequences" that rest on policy grounds. The most relevant canon of statutory construction advises that statutes should be construed so as to avoid an absurd result. See, e.g., St. Joseph's Hosp. \& Medical Center v. Maricopa County, 130 Ariz. 239, 245, 635 P.2d 527, 533 
Justice O'Connor has been criticized at times for departing unjustifiably from this "plain meaning" approach. One such occasion arose in Bowsher v. Merck \& Co. ${ }^{65}$ where her majority opinion came under fire from the dissent for paying insufficient attention to plain statutory language. The Court was considering the scope of the Comptroller General's statutory right to demand access to records pertaining to certain government contracts. The narrow issue was to determine what records could be said to "directly pertain to, and involve transactions relating to, the contract or subcontract." $\mathrm{Her}$ opinion began from this language, terming it "words of limitation designed to restrict the class of records to which access is permitted by requiring some close connection between the type of records sought and the particular contract." But she apparently thought that the language did not illuminate the problem of what connection was required between the records and the contract because she turned immediately to the legislative history for guidance in balancing the public and private interests at stake. ${ }^{68}$ Her solution, in accord with the lower court decisions, allowed the Comptroller General access to records of direct costs related to the contract, but denied access to records of "indirect costs" unless the contractor had allocated them as attributable to the particular contract. ${ }^{68}$

In separate opinions, Justices White and Blackmun criticized the Court for flouting the plain meaning of the statute. ${ }^{70}$ As these two opinions themselves found different "plain meanings," their central criticism may be weak. ${ }^{71}$ But they did identify a problem with Justice O'Connor's approach, which Justice Blackmun de-

(Ct. App. 1981) (O'Connor, J.). Yet this suggestion makes no distinction between these two kinds of "absurdity."

Bs 460 U.S. 824 (1983).

${ }^{68} 10$ U.S.C. $\S 2313(b)$ (1982). One of the four contracts was governed instead by the language of 41 U.S.C. $\$ 254$ (c) (1982), but the Court found that the slight differences in the wording of the statutes were immaterial. 460 U.S. at 827 n.3.

67460 U.S. at 831.

${ }^{68}$ Id. at $831-34$.

68 Id. at 840 .

${ }^{70} \mathrm{Id}$. at 853 (White, J., concurring in part and dissenting in part); id. at 862-63 (Blackmun, J., concurring in part and dissenting in part).

71 Justice White agreed that the Comptroller General had the right to inspect "direct cost" records, but would have permitted greater access to some "indirect cost" records as well. Id. at 846-47 (White, J., concurring in part and dissenting in part). Justice Blackmun would have held that the Comptroller General had no access even to "direct cost" records "when the terms of a contract are not tied to costs and the contractor makes no representations about costs during its negotiations with the Government." Id. at 865 (Blackmun, J., concurring in part and dissenting in part). 
scribed as a mere "nod in the direction of the statutory language" that went on to overturn the "balancing" and "accommodation" of interests already accomplished by Congress. ${ }^{72}$ In her defense, Justice O'Connor replied with "a well-settled canon of statutory construction that, where the language does not dictate an answer to the problem before the Court, 'we must analyze the policies underlying the statutory provision to determine its proper scope." "73

Justice O'Connor may have been correct that the bare statutory language at issue in Bowsher provided no resolution of the issue before the Court. But her analysis is problematic on two counts. First, she reached this conclusion without carefully analyzing the ordinary meaning of the words in the statute. ${ }^{74} \mathrm{~A}$ "plain meaning" orientation requires an initial detailed examination of what the statute says, and, unless it is to be used merely as a tool for reaching convenient results, this approach must be consistently applied. Second, while she properly noted that it is commonplace for courts to examine underlying policies when statutory language is unclear, ${ }^{75}$ this practice poses theoretical problems for someone, like Justice O'Connor, who has expressed concern about judicial interference in policy matters. Even when Congress has not spoken clearly on a given topic, the dangers of judicial preemption of the lawmaking function remain. The only added justification for policy analysis when the statutory language is unclear comes from the thought that some interpretation must be reached in order to decide the case. On these occasions, her concern about judicial responsibility to interpret the statute appears to override her con-

72 Id. at 860-61 (Blackmun, J., concurring in part and dissenting in part).

7s Id. at 831 n.7 (majority opinion) (quoting Rose v. Lundy, 455 U.S. 509, 517 (1982) (O'Connor, J.)).

" Cf. Secretary of the Interior v. California, $104 \mathrm{~S}$. Ct. 656, 661 (1984) (O'Connor, J.) (also giving only a brief analysis of the statutory language). For an example of a more careful analysis, consider her approach in Commissioner v. Engle, 104 S. Ct. 597, 603-04 (1984) (construing statutory language affecting the taxation of oil and gas producers).

${ }^{75}$ She adopted the same approach in her dissent in Smith v. Wade, 461 U.S. 30 (1983). The issue was whether and under what circumstances punitive damages were available in a case arising under the Civil Rights Act of 1871,42 U.S.C. $\$ 1983$ (1982). Because the statute is silent on this matter, the Court sought illumination from the common law as it existed in 1871 and concluded that punitive damages could be given where the defendant's conduct was reckless or motivated by evil intent. 461 U.S. at 39-45. Justice Rehnquist, also referring to the common law at the time the statute was passed, disagreed with the Court's holding. Id. at 60 n.3 (Rehnquist, J., dissenting). Justice O'Connor, in a separate dissent, found this "significant split in authority" just as uninformative as the statute itself: "The battle of the string citations can have no winner." Id. at 93 (O'Connor, J., dissenting). Instead, she turned for guidance to the policies underlying the statute. 
cern for judicial restraint in lawmaking. ${ }^{76}$

Taken together, these two problems with Justice O'Connor's approach in Bowsher and Securities Industry are especially troubling. The weaknesses of a "plain meaning" approach are illustrated in these cases by the dramatic interpretive disagreements among the Justices. ${ }^{77}$ Justice O'Connor is understandably worried that the judiciary will arbitrate among an array of policies and interests, in usurpation of the legislative role, if courts undertake to weigh policies whenever statutory language is "unclear." But the difference between proper judicial action and questionable judicial interference with the legislature rests on elusive insights into the ordinary meanings of language. Because few statutes requiring interpretation by the Court are models of clarity, it is difficult to see how Justice O'Connor's own "plain meaning" approach can adequately allay her concern about judicial lawmaking.

\section{B. "Activist" Judicial Restraint}

Some aspects of Justice O'Connor's position on the role of the judiciary are not confined by ordinary notions of judicial restraint. She is concerned to preserve the integrity of the system of separated powers, and she seems to suggest that the greatest present threat to this system has arisen from the gradual growth in federal judicial power. Thus, she advocates narrower limits on the judicial role and greater deference toward the powers held by coordinate branches of the federal government.

${ }^{76}$ For a different approach, suggesting that courts need not feel compelled to construe statutes where there is no solid statutory basis for their interpretation, see Easterbrook, Legal Interpretation and the Power of the Judiciary, 7 HaRv. J.L. \& PUB. PoL'y 87 (1984); Easterbrook, Statutes' Domains, 50 U. CHI. L. REv. 533 (1983). For a less radical critique of common statutory canons, see Posner, Statutory Interpretation-in the Classroom and in the Courtroom, 50 U. CHI. L. REv. 800 (1983).

Justice O'Connor does not object to applying certain well-established substantive judicial policies in statutory construction-for example, the rule of lenity, which requires a higher standard for resolving facial ambiguity against a defendant when interpreting a criminal statute. See, e.g., Dixson v. United States, 104 S. Ct. 1172, 1183 (1984) (O'Connor, J., dissenting). But cf. McElroy v. United States, 455 U.S. 642, 658 (1982) (O'Connor, J.) (refusing to apply the rule of lenity because interpretation "does not raise significant questions of ambiguity" when a statutory term is held to carry the court's interpretation of it at the time of enactment). Because the rule of lenity does not involve the courts in weighing competing policies to set out new law to fill gaps in the legislative scheme, it seems to pose less danger of judicial lawmaking.

${ }^{77}$ Even a consistent "plain meaning" approach has been the target of substantial criticism. See, e.g., Henry Friendly, Benchmarks 204-06 (1967) (discussing Justice Frankfurter's critique); Note, Intent, Clear Statements, and the Common Law: Statutory Interpretation in the Supreme Court, 95 HARv. L. REv. 892, 902-07 (1982). 
1. Review of Agencies and Officials. In most cases involving review of agency decisions, Justice O'Connor follows familiar paths. She respects agency expertise in complex, specialized fields and is deeply skeptical of judicial competence to review agency decisions in such areas. For example, in Sure-Tan, Inc. v. NLRB, ${ }^{78}$ her opinion for a majority of the Court upheld the NLRB's conclusions that illegal aliens were "employees" under the National Labor Relations Act" and that the employer had committed an unfair labor practice in reporting these aliens to the INS after they had voted in favor of union representation. Indeed, the Court overturned the Seventh Circuit's modification of the NLRB's initial remedies" ${ }^{80}$ on the ground that the courts "should not substitute their judgment for that of the Board in determining how best to undo the effects of unfair labor practices." ${ }^{\text {11 }}$ Despite her deference to agency expertise, however, Justice O'Connor accepts the traditional understanding that the Court must not defer to the agency when determining the scope of the agency's statutory grant of power. In ICC $v$. American Trucking Associations, ${ }^{82}$ she objected strongly to the majority's deference to the agency's interpretation of the scope of its own authority. Finding that the statutory language did not support the broad power claimed by the Commission, Justice O'Connor argued that "this Court is no more authorized than is the Commission to rewrite the law."

78 104 S. Ct. 2803 (1984).

79 National Labor Relations Act $\S 2(3), 29$ U.S.C. $\$ 152(3)$ (1982).

so $104 \mathrm{~S}$. Ct. at 2808 (summarizing the lower court's remedies in NLRB v. Sure-Tan, Inc., 672 F.2d 592, 603-06 (7th Cir. 1982)).

81 $104 \mathrm{~S}$. Ct. at 2813 . This action was rather surprising because, as Justice Brennan noted, the NLRB had fully acquiesced in the appellate court's modifications and had urged the Court to affirm them. Id. at 2817 (Brennan, J., dissenting). For Justice O'Connor, the primary concern was not to reach an outcome that was somehow satisfactory to the NLRB, but to attain the proper procedural posture between the agency and the courts. Id. at 2813 n.9 (O'Connor, J.). For opinions demonstrating similar deference to agency decisions, see Securities Indus. Ass'n v. Board of Governors of the Fed. Reserve Sys., 104 S. Ct. 2979, 2993 (1984) (O'Connor, J., dissenting) (advocating a similarly deferential approach despite the majority's warning that deference should not be permitted to emasculate the significance of judicial review); cf. Baltimore Gas \& Elec. Co. v. Natural Resources Defense Council, 462 U.S. 87, 105 (1983) (O'Connor, J.) (deferring to the Nuclear Regulatory Commission's judgments in an area within its scientific expertise). Her approach in Baltimore Gas is consistent with her opposition to the judiciary's undertaking frequent technical and scientific judgments in abortion cases. See supra notes $41-42$ and accompanying text.

s2 104 S. Ct. 2458 (1984).

os Id. at 2472 (O'Connor, J., dissenting). She similarly objected to an agency's unauthorized "arrogation of power" in NLRB v. City Disposal Sys., 104 S. Ct. 1505, 1517 (1984) (O'Connor, J., dissenting) (concerning NLRB's definition of "concerted activity" under statute). She typically follows the presumption that agency regulations and interpretations of law are reasonable exercises of delegated power from Congress, especially when they reflect 
In addition to these fairly standard positions, Justice O'Connor has pointed out a very different problem in the relations between agencies and the courts. Even a deferential judiciary can interfere with agency operations if it is willing to hear every complaint that rests, no matter how tenuously, on agency conduct. Her exceptional concern that the judiciary not unduly interfere with agencies and officials is presented most clearly in two important cases involving the issue of standing to sue. In both cases, she narrowed a private party's ability to obtain judicial review of agency actions.

The first case, Allen $v$. Wright, ${ }^{84}$ raised the issue of when a plaintiff has standing to obtain judicial review of agency conduct. The plaintiffs were parents of black public school children. They brought a nationwide class action, alleging that the Internal Revenue Service (IRS) had not adopted adequate measures to fulfill its obligation to deny tax-exempt status to racially discriminatory private schools. The plaintiffs requested a declaratory judgment that the challenged IRS tax-exemption practices were unlawful and sought injunctive relief. In her opinion for a divided Court, Justice O'Connor held that the parents lacked standing to bring the suit. ${ }^{85}$

Justice O'Connor prefaced her analysis with a few general remarks on the standing doctrine. In her view, the requirements for standing "state fundamental limits on federal judicial power in our system of government." quiry into standing must be conducted in a manner consistent with separated governmental powers and must be informed by the "Art[icle] III notion that federal courts may exercise power only in the last resort, and as a necessity." "87 Two essential components of the standing doctrine were at issue: first, whether the plaintiffs had alleged a distinct and palpable injury; and second, whether any

longstanding consistency of interpretation by the agency. See, e.g., Commissioner v. Tufts, 461 U.S. 300, 319-20 (1983) (O'Connor, J., concurring) (deferring to longstanding IRS regulations); United States v. Clark, 454 U.S. 555, 565 (1982) (O'Connor, J.) (deferring to government personnel regulations that have been followed consistently). But see, e.g., Commissioner v. Engle, 104 S. Ct. 597, 608 (1984) (O'Connor, J.) (refusing to defer to an "unreasonable" IRS position). But in City Disposal, she did not frame the issue in this manner and did not set out the initial presumption favoring the NLRB's interpretation. Perhaps she did not consider that doctrine to be longstanding, or perhaps she views the presumption more narrowly when an agency interpretation affects its own statutory grant of power.

s4 104 S. Ct. 3315 (1984).

ss Id. at 3319.

so Id. at 3324 .

s7 Id. at 3325 (quoting Chicago \& Grand Trunk Ry. v. Wellman, 143 U.S. 339, 345 (1892)). 
such injury was "fairly traceable" to the challenged action so that relief from the injury would be likely to follow upon a favorable decision. ${ }^{88}$

In their complaint, the parents had alleged two injuries. The first injury was the direct harm done to them by the mere fact of government financial aid to discriminatory private schools. Justice O'Connor denied that this claim represented any distinct and palpable injury to the parents. Instead, they were claiming either an abstract injury based generally on the government's alleged violation of the law, or an abstract stigmatizing injury based on alleged discrimination against others of their own race. ${ }^{89}$

The second injury alleged by the parents was their children's diminished ability to receive an education in a racially integrated school. Justice O'Connor had no doubt that this was a distinct and palpable injury, "one of the most serious injuries recognized in our legal system." Yo Yet she denied that the injury was fairly traceable to the challenged government conduct.

She approached this issue in two stages. First, and more conventionally, she argued that there was only an indirect line of causation between the challenged IRS conduct and the alleged segregation in the schools attended by the plaintiffs' children. The parents had not alleged that enough racially discriminatory private schools in their communities received tax exemptions for withdrawal of those exemptions to make an appreciable difference in public-school integration. ${ }^{.1}$ She also argued that it was pure speculation whether withdrawal of a tax exemption from any particular school would lead to a change in that school's policies. ${ }^{92}$ The dis-

ss 104 S. Ct. at 3325.

"Id. at $3326-27$. Justice Brennan very briefly criticized the Court's analysis of the alleged stigmatizing injury. Id. at 3335 n.3 (Brennan, J., dissenting).

so Id. at 3328 (majority opinion).

91 Id. Justice Brennan strongly disagreed with this contention. Id. at 3337-38 (Brennan, J., dissenting). Justice $O^{\prime}$ Connor's response relied on a different interpretation of the facts alleged in the complaint. Id. at $3328 \mathrm{n} .23$ (majority opinion).

92 Id. at 3328-29. In contrast, Justice Stevens argued that the "causation analysis is nothing more than a restatement of elementary economics: when something becomes more expensive, less of it will be purchased." Id. at 3344 (Stevens, J., dissenting). Justice O'Connor's opinion for the Court in Watt v. Energy Action Educ. Found., 454 U.S. 151 (1981), bears comparison on this issue. In Energy Action, the Court granted California standing to challenge the Interior Department's methods for accepting bids on oil and gas rights. Id. at 162. By law, California had a financial stake in federal oil and gas leasing. The state complained that its return on the leases was diminished because the Interior Secretary refused to experiment with alternative bidding systems. The injury claimed was found to be fairly traceable to the challenged conduct. Id. at 161-62. Yet it was not intuitively obvious that the experimentation requested would improve California's return: that outcome would 
senters strongly criticized these arguments, but the disagreements about the application of the "fairly traceable" requirement, while practically significant, were at least controversies within the scope of traditional standing doctrine.

Justice O'Connor's second argument was altogether unconventional, however. She argued that the principle of separation of powers helps to show why such an indirect link between the challenged conduct and the alleged injury was insufficient to provide standing to bring the suit. Any other conclusion "would pave the way generally for suits challenging, not specifically identifiable Government violations of law, but the particular programs agencies establish to carry out their legal obligations." "93 In other words,

[the principle that government should have wide latitude in dispatching its internal affairs] counsels against recognizing standing in a case brought, not to enforce specific legal obligations whose violation works a direct harm, but to seek a restructuring of the apparatus established by the Executive Branch to fulfill its legal duties. The Constitution, after all, assigns to the Executive Branch, and not to the Judicial Branch, the duty to "take Care that the Laws be faithfully executed." ... We could not recognize respondents' standing in this case without running afoul of that structural principle. ${ }^{94}$

This language interjects a new element into the doctrine of standing by suggesting that separation of powers has a "role to play in giving meaning to [standing] requirements."

depend on further actions to be taken by the Interior Secretary, namely, the adoption of one or another system. Id. Thus, Energy Action and Allen seem to be at odds on the causation issue. They may be distinguishable on the grounds that while Energy Action only involved one intermediate actor, and his motivation in the matter was fairly clear, in Allen the intermediate actors included a large number of schools with a variety of conflicting interests. The cases might also be distinguishable on the ground that the "intermediate actor" in Energy Action was in fact one of the parties to the litigation. But Justice O'Connor did not discuss or attempt to distinguish Energy Action in her opinion in Allen.

$104 \mathrm{~S}$. Ct. at 3329.

or Id. at 3330 (quoting U.S. ConsT. art. II, § 3) (footnote omitted). As Justice Stevens observed, however, the Court would only be fulfilling the traditional judicial responsibility " "to say what the law is." " $104 \mathrm{~S}$. Ct. at 3348 (Stevens, J., dissenting) (quoting Marbury v. Madison, 5 U.S. (1 Cranch) 137, 177 (1803)).

${ }_{95} 104 \mathrm{~S}$. Ct. at 3330 n.26. These remarks seem to be dicta, since she could have rested the Court's holding simply on her conclusion that "[ $t]$ he links in the chain of causation between the challenged Government conduct and the asserted injury are far too weak for the chain as a whole to sustain respondents' standing." Id. at 3329. But she insisted on explaining that conclusion by analyzing the "idea of separation of powers that underlies standing doctrine." Id. 
O'Connor seems to offer a "sliding-scale approach" to standing. She argues that if a suit before the Court raises separation-of-powers concerns, then, depending on the extent of those concerns, the plaintiff's injury would have to be correspondingly more directly traceable to the challenged conduct. In particular, she argues that the Court should distinguish between two different kinds of challenged conduct. Where a plaintiff seeks to challenge government violations of specific legal obligations, standing could be based on an injury less directly traceable to the challenged conduct. Where a plaintiff seeks to restructure the executive branch's approach to fulfilling its legal duties, standing must be based on an injury that is more directly traceable to the challenged conduct. ${ }^{96}$

Justice Stevens noted in dissent that this suggestion may confuse standing (who can bring suit) with justiciability (what issues a court can decide) by suggesting that standing doctrine should focus not only on the party bringing the suit, but also on the issue presented for adjudication. ${ }^{97} \mathrm{He}$ further criticized this separationof-powers approach because it provided no guidance to lower courts "in determining when it is appropriate to require a more rigorous redressability showing because of separation of powers concerns, or how redressability can be demonstrated in a case raising separation of power [sic] concerns."

The first criticism of Justice O'Connor's suggested approach is powerful, but not fatal. Her approach does combine, to some extent, the issues of standing and justiciability, which had developed as separate inquiries. But these issues are based on common constitutional and prudential concerns about the judicial function. Indeed, she tried to show that the two issues are not entirely separate even under current judicial doctrine. She argued that the soundness of a plaintiff's claim often does affect, and should affect, a court's judgment about whether the plaintiff has standing. ${ }^{9 \theta}$ In

-8 See id. at 3333 (complaint alleges no connection "direct enough to overcome the substantial separation-of-powers barriers to a suit seeking an injunction to reform administrative procedures").

97 Id. at 3345-46 (Stevens, J., dissenting).

os Id. at 3346 n.10.

or Id. at 3330 (majority opinion). Justice Brennan disagreed with her evaluation of the facts: "More than one commentator has noted that the causation component of the Court's standing inquiry is no more than a poor disguise for the Court's view of the merits of the underlying claims. The Court today does nothing to avoid that criticism." Id. at 3341 (Brennan, J., dissenting) (footnote omitted). Some of the Court's prior language, however, would accommodate her test. For example, the Court has said that "the standing question is whether the plaintiff has 'alleged such a personal stake in the outcome of the controversy' as to warrant his invocation of federal-court jurisdiction and to justify exercise of the court's 
an era during which lower courts have intervened heavily in the administration of government operations, such as schools, prisons, and the like, she would restrict the occasions for extraordinary judicial action to those where the plaintiff's injury is quite directly tied to the alleged wrong. Where a complaint raises questions about the propriety of judicial intervention, the plaintiff's stake must be correspondingly greater to overcome these doubts. The result is still to focus "primarily on the party" bringing the suit, and only secondarily on the issue involved. ${ }^{100}$

Justice Stevens's second criticism is more troubling, especially in light of Justice O'Connor's concern that the Supreme Court should provide clear guidance to lower courts. ${ }^{101}$ As she pointed out, current standing doctrine is itself "not susceptible of precise definition." ${ }^{102}$. Nonetheless, her requirement-that plaintiff's alleged injury must be more directly traceable to the challenged conduct when the suit implicates separation-of-powers concernsrepresents a broad and vague balancing test, which is likely to create additional confusion in this area.

Furthermore, it is unclear exactly what kind of case will raise separation-of-powers concerns. The distinction that Justice O'Connor draws between suits involving government violation of a specific legal duty and those involving the restructuring of executive-branch approaches to fulfilling legal duties may not be very useful: very often the two categories will converge. For example, Allen presented the claim that the IRS's approach to fulfilling a specific legal duty-denying tax-exempt status to racially discriminatory private schools-was so inadequate that it violated that duty. As Justice Stevens noted, "the separation of powers tolerates quite a bit of 'restructuring' in order to eliminate the effects of racial segregation."103 Thus, her approach seems to require courts

remedial powers on his behalf." Warth v. Seldin, 422 U.S. 490, 498-99 (1975) (second emphasis added) (quoting Baker v. Carr, 369 U.S. 186, 204 (1962)). Justice Stevens used this passage somewhat differently in order to show that standing concentrates on the party rather than on the issue. Allen, $104 \mathrm{~S}$. Ct. at 3346 (Stevens, J., dissenting).

${ }^{200}$ United States v. Richardson, 418 U.S. 166, 174 (1974) (emphasis in original) (citing Flast v. Cohen, 392 U.S. 83, 99 (1968)). Justice Stevens quoted this passage in order to criticize Justice O'Connor's approach. $104 \mathrm{~S}$. Ct. at 3346 (Stevens, J., dissenting).

${ }^{101}$ See, e.g., cases cited supra note 49 . The most urgent questions here would be how to determine what kind of injury would qualify as being "more directly traceable," and how to specify the class of circumstances in which a "more directly traceable" injury is required in order to gain standing.

${ }^{102} 104 \mathrm{~S}$. Ct. at 3325.

${ }^{103} \mathrm{Id}$. at $3346 \mathrm{n} .10$ (Stevens, J., dissenting). One could also view the issue in Allen as a clash between Congress and the executive branch because the IRS allegedly failed to implement specific provisions of the Internal Revenue Code effectively. Justice O'Connor's desire 
to decide whether a specific legal duty has been violated at the preliminary stage when the standing issue is determined, without the more thorough examination that this issue often demands. To the extent that this is true, her approach may simply provide courts with a new weapon for reaching desired results without addressing the particular substantive concerns that would otherwise be necessary to those results. ${ }^{104}$

Justice O'Connor's approach can be defended, however, on the ground that respect for the coordinate branches of government suggests that only as a last resort should courts become involved in restructuring executive-branch approaches to carrying out legal obligations. This concern can be illustrated by considering the theoretical problems raised in other contexts by detailed judicial oversight of various government operations. ${ }^{105}$ At the same time, however, courts must not shirk their responsibility to protect the rights that the Constitution or Congress has conferred on individuals. Justice O'Connor's approach tries to accommodate these two concerns in a manner more respectful of the principle of separation of powers: when the potential interference with agency operations is greater, courts will only hear a plaintiff who can allege a more direct harm. Her approach may cause added confusion and will probably lead to some premature decisions on the soundness of plaintiffs' claims. Moreover, some wrongs alleged to have been committed by the executive branch are likely to go unredressed. These costs can be justified only when set against her overriding concern to establish limits upon the intrusiveness of judicial power.

to restrict judicial involvement in this fray would then seem to be at odds with her advocacy of fairly stringent judicial review of agency interpretations of law that would expand the agency's own statutory grant of power. See ICC v. American Trucking Ass'ns, $104 \mathrm{~S}$. Ct. 2458, 2468-72 (1984) (O'Connor, J., dissenting) (discussed supra notes 82-83 and accompanying text); NLRB v. City Disposal Sys., 104 S. Ct. 1505, 1517 (1984) (O'Connor, J., dissenting) (rejecting the NLRB's "arrogation of power" over all collective-bargaining contracts and contract disputes).

${ }^{204}$ Indeed, Allen may be practically dispositive of the substantive claim. In theory, at least, the plaintiffs could have stayed in court by alleging that judicial action would "appreciably" affect public-school integration. $104 \mathrm{~S}$. Ct. at 3328. But it is not clear that any plaintiffs would ever have more facts to allege than those put forward by the plaintiffs in Allen. If this is so, then Justice O'Connor's approach, by precluding anyone from initiating review of the IRS regulations, could permit schools to evade integration goals more easily.

${ }^{103}$ See, e.g., Rhodes v. Chapman, 452 U.S. 337, 349-50, 351-52 (1981) (federal judges should avoid intruding into state prison administration unless clear violations of the eighth amendment are demonstrated); Milliken v. Bradley, 418 U.S. 717, 746 (1974) (denying that district court judges have a "free hand" to fashion school-desegregation relief embracing more than a single school district). 
A second case, Block v. Community Nutrition Institute, ${ }^{106}$ dealt with whether the ultimate consumers of dairy products could obtain judicial review of milk market orders issued by the Secretary of Agriculture pursuant to statute. ${ }^{107}$ Justice O'Connor concluded, for a unanimous Court, that Congress had precluded consumers from obtaining judicial review of milk market orders. In taking this position, she articulated a narrow view of the Court's presumption favoring judicial review of administrative action. ${ }^{108}$ In particular, she objected to the lower court's use of Abbott Laboratories $v$. Gardner, ${ }^{109}$ where the Supreme Court had held that "only upon a showing of 'clear and convincing evidence' of a contrary legislative intent should the courts restrict access to judicial review."110 Justice O'Connor argued that this standard should not be taken in a "strict evidentiary sense" of unambiguous proof, so long as "congressional intent to preclude judicial review is "fairly discernible in the statutory scheme." "111 In her view, congressional intent to preclude certain persons from obtaining judicial review of agency action need not rest on specific language or even on specific legislative history, but could be inferred from the statutory scheme as a whole. ${ }^{112}$ This view allowed the presumption favoring judicial review of administrative action to be overcome more easily.

In both of these standing cases, Justice $O^{\prime}$ Connor led the Court in curtailing a private party's ability to involve the Court in

${ }_{108} 104$ S. Ct. 2450 (1984).

107 The statutory authority was given in the Agricultural Marketing Agreement Act of 1937, ch. 296, 50 Stat. 246 (codified as amended at 7 U.S.C. $\$ 601$ (1982)).

${ }_{103}$ Justice O'Connor could have reached the same result simply with her argument that the statutory scheme here was explicit enough to overturn the presumption in favor of judicial review. The facts of the case did not require that she weaken the usual force of the presumption. See $104 \mathrm{~S}$. Ct. at 2454-55.

109387 U.S. 136 (1967).

${ }^{110} \mathrm{Id}$. at 141 (quoting Rusk v. Cort, 369 U.S. 367, 379-80 (1962)).

$121104 \mathrm{~S}$. Ct. at 2457 (quoting Association of Data Processing Serv. Orgs. v. Camp, 397 U.S. 150, $157(1970))$.

$112104 \mathrm{~S}$. Ct. at 2456 . Her strongest statement was that "when a statute provides a detailed mechanism for judicial consideration of particular issues at the behest of particular persons, judicial review of those issues at the behest of other persons may be found to be impliedly precluded." Id. Contrary to this approach, a leading commentator has emphasized the need for more definite expressions of legislative intent to preclude review. See Louis Jaffe, Judicial Control of Administrative Action 357-59 \& n.181 (1965). Moreover, in Barlow v. Collins, 397 U.S. 159, 167 (1970), the Court had said that "judicial review is ordinarily inferred where congressional intent to protect the interests of the class of which the plaintiff is a member can be found; in such cases, unless members of the protected class may have judicial review the statutory objectives might not be realized." This statement and the congressional declaration of purposes in the statute at issue in Community Nutrition, see 7 U.S.C. $\$ 602(2)$, (4) (1982), which evinced concern for consumer interests, presented a strong argument in support of standing. 
oversight of administrative agencies. ${ }^{113} \mathrm{Her}$ primary concern was to limit the judicial function in a government of separated powers. But her restrained approach may be thought inappropriate when applied to the workings of administrative agencies, whose accountability to Congress, or even to the President, has often become almost fictional. ${ }^{114}$

Nonetheless, administrative agencies are authorized and funded by Congress, and most of them would seem to be a part of the executive branch. If those branches are not adequately overseeing administrative agencies, then in her view the problem should be corrected where it has arisen. Such shortcomings do not justify a reactive expansion of the judicial function, which would lead to undue interference with the policymaking branches. ${ }^{116}$

2. Review of Legislation. Justice O'Connor's concern about judicial interference with the legislative process, which is apparent in her attempts to apply a "plain meaning" approach to statutory construction, is also illustrated by her approach to judicial review of legislation. She seeks to have the Court, wherever feasible, exercise its power to review legislation in a way that minimizes the constitutional impediments to legislative action. For example, she accepts the practice of construing statutes to avoid resolution of constitutional questions except when absolutely necessary. ${ }^{116} \mathrm{~A}$ more unusual aspect of her approach to judicial review is her notion that when the Court is forced to strike down legislation and can choose among different constitutional provisions in doing so, it should invoke the provision that will pose the least obstacle to further legislative action in that area.

This approach was suggested in her dissent in ASARCO Inc. $v$. Idaho State Tax Commission. ${ }^{117}$ Idaho had levied corporate in-

11s The substantive context of Block is ambiguous, since her narrow view of standing doctrine led to a result that protected business interests against consumers but also denied review of regulatory orders that restricted competition in the milk market.

114 See, e.g., U.S. President's Advisory Council on Executive Organization, A New Rggulatory Framework: Report on Selected Independent Regulatory Agencies 4, 5, 1416 (1971); U.S. President's Comm. on Administrative Management, Report of the Committee with Studies of Administrative Management in the Federal Government 39-40 (1937).

115 In return for the wide latitude she allows to administrative agencies, she appears to demand that they observe certain procedural safeguards in taking action or reaching decisions. See, e.g., Shepard v. NLRB, 459 U.S. 344, 352 (1983) (O'Connor, J., dissenting) (agreeing with the Court that the Board's decision was reasonable, but arguing for remand to the Board because it failed to provide an adequate explanation of its decision).

118 See, e.g., South Carolina v. Regan, 104 S. Ct. 1107, 1125 (1984) (O'Connor, J., concurring) (construing a statute so as to leave the Court's original jurisdiction unaffected).

11758 U.S. 307 (1982). Her dissent also applied to a companion case, F.W. Woolworth 
come taxes on a corporation that was neither incorporated nor domiciled in Idaho, but which operated a silver mine and did some other business in the state. The state sought to include in the corporation's taxable income some amounts that the corporation received from subsidiary corporations having no other connection with the state. The Court held that this state action violated the due process clause of the fourteenth amendment because there was no rational relation between these amounts and the intrastate value of the corporation. ${ }^{118}$

Justice O'Connor disagreed with the Court's decision to overturn the state action. ${ }^{119}$ But she particularly denounced the Court's "constitutional shortsightedness" in basing its decision on the due process clause rather than the commerce clause. ${ }^{120}$ Under the commerce clause, Congress has the authority to regulate interstate commerce, and Congress can exercise this power to permit the states to restrain interstate commerce in ways that would be impermissible absent congressional authorization.

Consistent with this principle, it has long been established that Congress generally has the power to "overrule" a decision of this Court invalidating state legislation on Commerce Clause grounds. . . . By contrast, Congress generally cannot waive a ruling of this Court decided under the Due Process Clause. Accordingly, this Court's "threshold" for invalidating state legislation should be considerably higher under the Due Process Clause than under the Commerce Clause. ${ }^{121}$

She argued that the Court should decline to invoke a more restrictive constitutional provision when the substantive area of law could be better addressed outside the courts. This is particularly true of interstate tax law. Although the Court has the "authority" to strike down state taxes, "only Congress has both the ability to canvass the myriad facts and factors relevant to interstate taxation and the power to shape a nationwide system that would guarantee the States fair revenues and offer interstate businesses freedom

Co. v. Taxation \& Revenue Dep't, 458 U.S. 354 (1982).

118458 U.S. at 328-30. The contested statute was Idaho's version of the Uniform Division of Income for Tax Purposes Act. IDaho CoDE § 63-3027 (1976 \& Supp. 1981).

119458 U.S. at 349 (O'Connor, J., dissenting).

${ }^{120}$ Id. at 350 . The Court did not reach the commerce clause argument, having already found the state action invalid under the due process clause. The Court also took no position on the extent of federal authority to legislate in this area after its decision. Id. at $327 \mathrm{n} .23$ (majority opinion).

${ }^{121}$ Id. at 350 n.14 (O'Connor, J., dissenting) (citations omitted). 
from strangulation by multiple paperwork and tax burdens."122

Justice O'Connor's proposal-that the Court should adopt varying "thresholds" for invoking different constitutional provisions to strike down legislation, depending on the extent of judicial interference with other parts of government and on the amount of disruption likely to ensue from that interference-is consistent with her understanding of the judicial role. Although her proposal might lead the Court to diverge from trends established in some of its precedents, for example, the application of the due process clause in past cases like $A S A R C O,{ }^{123}$ it might help to confine the extent of judicial interference with the legislative power.

Moreover, her approach poses no far-reaching theoretical problems, so long as it is understood to apply only to situations where the challenged statute violates more than one constitutional provision. In those instances, her approach would not change the outcome of the case, in the sense that it would not affect whether the statute is struck down or allowed to stand. It merely recognizes that the Court's decision to invalidate a statute may erect a further obstacle to legislative resolution of a particular problem and attempts to minimize that obstacle.

Justice O'Connor's approach raises more serious questions, however, if her statement that "this Court's 'threshold' for invalidating state legislation should be considerably higher under the Due Process Clause than under the Commerce Clause"124 is meant to apply more broadly. Suppose, for example, that a state statute may violate the due process clause, but does not violate the commerce clause. Her proposal could be read to mean that in such a case the due process clause should be applied with greater circumspection merely because it erects a stubborn judicial obstacle to any further state or federal legislation. If that is so, then her approach could change the outcome by more easily allowing the statute to stand. In effect, her approach would impose a prudential reluctance to restrict state action on constitutional provisions that are intended to restrict state action to at least some extent. This approach certainly would have much more dramatic implications than the result in $A S A R C O$ itself seemed to suggest. ${ }^{125}$

112 Id. at 331 . She later elaborated upon the reasons why judicial interference in this area should be avoided and why the Court "should not so confidently pre-empt the Congress." Id. at 350-53.

12s See id. at $327 \mathrm{n} .23$ (majority opinion) (citing cases).

124 Id. at 350 n.14 (O'Connor, J., dissenting).

125 If her approach is not meant to narrow due process restrictions, however, it may lead to more, not less, judicial interference with legislative solutions. For example, where a 
Another example of this approach is Justice O'Connor's concurring opinion in Zobel $v$. Williams, ${ }^{126}$ where the Court struck down an Alaska statute that established a program to distribute the state's mineral income to its citizens in amounts that varied according to the length of time that each citizen had resided in Alaska since it entered the Union. The Court held, in an opinion by Chief Justice Burger, that the program violated the equal protection clause because the distinction it made between newer and older residents was not even minimally related to any legitimate state purpose. ${ }^{127}$

Justice O'Connor concurred in the judgment, but offered a different rationale. To begin with, she was much more sympathetic to the state interests, and she rejected the Court's sweeping determination that Alaska's objective here was wholly illegitimate:

A desire to compensate citizens for their prior contributions is neither inherently invidious nor irrational. Under some circumstances, the objective may be wholly reasonable. Even a generalized desire to reward citizens for past endurance, particularly in a State where years of hardship only recently have produced prosperity, is not innately improper. ${ }^{128}$

In her view, the Court had gone too far because its opinion ensured that "any governmental program depending upon a "past contributions' rationale will violate the Equal Protection Clause."129

Nevertheless, Justice O'Connor concluded that Alaska's pro-

particular statutory scheme violates both the commerce clause and the due process clause, invoking the commerce clause alone might only lead to the enactment, by Congress or with its consent, of a similarly invalid scheme, which the courts would then have to strike down again on due process grounds. Thus, it might be better to invalidate it under the more restrictive provision in the first place, so that legislative bodies may be more certain of the precise obstacles to further enactments.

Actually, the broader interpretation of her language-as an attempt to narrow due process restrictions against the states-is compatible with her views on federalism and on substantive constitutional issues, which are discussed infra notes 138-292 and accompanying text.

${ }^{188} 457$ U.S. 55 (1982).

${ }^{127}$ Id. at 60-64. The statutory scheme was enacted under an authorizing provision in the state constitution. Alaska Const. art. IX, § 15 (1980); Alaska Stat. $\S 93.23 .010-.100$ (1980) (repealed 1982).

${ }^{128} 457$ U.S. at 72 (O'Connor, J., concurring) (footnote omitted). A footnote to this passage, $i d$. n.1, offered several examples of state goals that she thought might be legitimately served by rewarding citizens for their past contributions. Thus, she thought that her invocation of the privileges and immunities clause imposed a narrower restraint on state action than did the Court's equal protection analysis.

128 Id. at 73 n.2. 
gram was invalid under the privileges and immunities clause. ${ }^{130}$ She argued that the state program directly threatened the recognized constitutional "right to travel."131 Moreover, she attempted to link this right to the privileges and immunities clause by a historical analysis, showing that the clause was originally tied to a guarantee of "free ingress and regress to and from any other State." "132 Although Alaska's objective in this particular instance was not an inherently illegitimate use of its sovereign powers, it necessarily would impose a burden on citizens of other states in exercising their fundamental right to establish a new residence in Alaska. ${ }^{133}$ In her view, a state can make distinctions among its own citizens in order to reward specific past contributions, but it cannot use its powers more generally to discriminate against citizens of other states. ${ }^{134}$

Both the Court's opinion and Justice Rehnquist's dissent disagreed with her application of the privileges and immunities clause. They referred to prior decisions holding that this clause merely assures that nonresidents of a state will be on equal footing with residents, without controlling a state government's powers over its own citizens. ${ }^{135}$ In reply, she argued that Alaska's program burdened citizens of other states who were deciding whether to reside in Alaska and that it was irrelevant that the discrimination did not gain force until after the nonresident moved into the state.

130 "The Citizens of each State shall be entitled to all Privileges and Immunities of Citizens in the several States." U.S. CoNST. art. IV, § 2, cl. 1.

${ }^{131} 457$ U.S. at 74, 78-81 (O'Connor, J., concurring).

132 Id. at 79 (quoting ARTicles of ConfEDERATion art. IV). She argued that this phrase was only omitted from the Constitution's version of the clause because it was redundant. 457 U.S. at 79-80 (O'Connor, J., concurring).

${ }_{18 s} 457$ U.S. at 72-73 (O'Connor, J., concurring) (citing Paul v. Virginia, 75 U.S. (8 Wall.) 168,180 (1869)).

134 She arrived at the latter conclusion by applying the privileges and immunities test that had been developed by the Court in cases such as Hicklin v. Orbeck, 437 U.S. 518 (1978). First, the right asserted by a nonresident must be "fundamental" in order to gain protection: here she identified the right to establish residence in a new state. Second, the state still may burden such a right if it can show that nonresidents are a peculiar source of an evil at which the statute is directed and that its discrimination bears a substantial relationship to that evil. She concluded that Alaska could not make either showing. 457 U.S. at 76-78 (O'Connor, J., concurring).

${ }^{235} 457$ U.S. at 59 n.5 (majority opinion); id. at 84 n.3 (Rehnquist, J., dissenting) (the clause "was designed to insure to a citizen of State A who ventures into State B the same privileges which the citizens of State B enjoy" ") (quoting Toomer v. Witsell, 334 U.S. 385, 395 (1948)). Justice Brennan approved of her emphasis on the "right to travel," but agreed with prior decisions holding that the right need not be tied particularly to the privileges and immunities clause or any other constitutional provision. 457 U.S. at 66-67 (Brennan, J., concurring). 
"Each group of citizens who migrated to Alaska in the past, or chooses to move there in the future, lives in the State on less favorable terms than those who arrived earlier."136

Justice O'Connor's creative application of the privileges and immunities clause in Zobel is not altogether implausible. Her aim was to allow each state greater power to make just distinctions among its citizens, without permitting the state to discriminate against citizens of other states. ${ }^{137} \mathrm{Her}$ approach demonstrates once again her determination to avoid striking down legislation on broad grounds of due process or equal protection when some other provision can be found that erects less formidable obstacles to the exercise of state powers.

Justice O'Connor's opinions in these cases illustrate her willingness to take nontraditional positions in order to restrain judicial activity. In Allen and Block, she sought to raise the threshold for judicial involvement in disputes over agency actions. In ASARCO and Zobel, she argued that the Court should exercise its power to review legislation in a manner that would create the least possible limitation on the scope of legislative action. Both of these positions can be considered "activist" because they call for the Court to adopt new approaches in cases that could have been disposed of in more conventional ways. But these positions also require the Court to be more circumspect in its relations with the political branches of government. What is unusual about her stance is the vigor with which she seeks to curb what she supposes to be actual and threatened excesses of judicial power.

Thus, in Justice O'Connor's view, "judicial restraint" translates into a very cautious assertion of judicial power. Yet it is not always the same thing as doctrinal caution; it may demand aggres-

${ }^{138} 457$ U.S. at 75 (O'Connor, J., concurring).

${ }^{137}$ Thus, Justice O'Connor's opinion in Zobel also reflects her views about federalism, which focus on the logical implications of statehood as an independent base of state power. In Zobel, however, state power is shown to be bounded by the necessary implications of a federal union, especially "the constitutional purpose of maintaining a Union rather than a mere 'league of States." "Id. at 72-73 (quoting Paul v. Virginia, 75 U.S. (8 Wall.) 168, 180 (1869)).

Justice O'Connor's dissent in ASARCO is also relevant on this point. Although in $A S A R C O$ she sought to avoid obstacles to congressional power, her concern was also for the states, since her opinion suggested that she would expect Congress and the states to act jointly in addressing the issues of tax apportionment raised in that case. ASARCO, 458 U.S. at 349 (O'Connor, J., dissenting). Furthermore, she complained in ASARCO about the emerging judicial doctrines concerning the apportionment of business taxes among the states, which she thought were too restrictive of state taxing powers. Id. at 344-45. Justice O'Connor's approach to federalism issues is discussed infra notes 138-205 and accompanying text. 
siveness, but aggressiveness in service of the main objective, which is to restrain the scope of judicial action. As can be seen from these cases, there are troublesome areas in which she has had difficulty translating her particular form of judicial restraint into a consistent approach. But the occasional difficulties in drawing out the precise ramifications of her proposals should not obscure the innovative direction of her judicial approach.

\section{Federalism and the Court}

Before coming to the Supreme Court, Justice O'Connor served in several prominent state government posts. Not unexpectedly, she has emerged as a staunch proponent of at least a "bare bones" federalism. Consistently with her views on judicial restraint, she does not seek the great explosion in federal court activity that would probably be necessary to turn the clock back on the vast historical expansion of federal power. But she does try to put some restraints on federal action in order to protect the independent mechanisms of state government. In her view, the states are separately functioning political units that must be permitted to operate, within their necessarily limited sphere, with as much autonomy as possible.

\section{A. Federal Legislation as a Limitation on State Power}

1. Tenth Amendment Limitations on Federal Power. Justice O'Connor has set forth her view of federalism most fully in cases in which a state has invoked the tenth amendment to seek invalidation of direct impositions created by federal legislation. Her use of the tenth amendment to limit Congress's broad power to regulate interstate commerce stems from the Court's decision in National League of Cities $v$. Usery ${ }^{138}$ in 1976. As the law stood before the Court's recent decision in Garcia v. San Antonio Metropolitan Transit Authority, ${ }^{139}$ the Court would invalidate federal enactments that met three tests: they must regulate the states as states, they must address matters that are indisputably attributes of state sovereignty, and they must directly impair state efforts to structure integral operations in areas of traditional state governmental functions. ${ }^{140}$ National League of Cities, however, was the only in-

138 426 U.S. 833 (1976), overruled, Garcia v. San Antonio Metro. Transit Auth., 105 S. Ct. 1005 (1985).

139 105 S. Ct. 1005 (1985).

${ }^{140}$ See, e.g., Hodel v. Virginia Surface Mining \& Reclamation Ass'n, Inc., 452 U.S. 264, 
stance in which the Court invalidated a federal law on those grounds.

Federal Energy Regulatory Commission $v$. Mississippi $(F E R C)^{141}$ gave the Court a further opportunity to consider the scope of its tenth amendment doctrine. Mississippi and one of its public commissions invoked the amendment to challenge provisions of the Public Utility Regulatory Policies Act of $1978^{142}$ that required state utility commissions to consider adopting and implementing federal rate, design, and regulatory standards and that required state commissions to follow certain notice and comment procedures when considering the proposed federal standards.

In an opinion by Justice Blackmun, the Court first found that Congress had the power to preempt the field of private-utility regulation. ${ }^{143}$ It then held that these particular requirements did not violate the tenth amendment because they involved no "compelled exercise of Mississippi's sovereign powers. And, equally important, they do not set a mandatory agenda to be considered in all events by state legislative or administrative decisionmakers. As we read them, [the provisions] simply establish requirements for continued state activity in an otherwise preemptible field."144

Justice O'Connor's strong dissent presented her views on federalism in a most direct manner, opposing what she saw as the Court's "fundamental misunderstanding of the role that state governments play in our federalist system."145 She argued that the federal provisions violated the National League of Cities doctrine as well as constitutional history by "conscript[ing] state utility commissions into the national bureaucratic army."146 As she explained:

State legislative and administrative bodies are not field offices of the national bureaucracy. Nor are they think tanks to which Congress may assign problems for extended study. Instead, each State is sovereign within its own domain, governing its citizens and providing for their general welfare. While the Constitution and federal statutes define the boundaries of that domain, they do not harness state power for na-

287-88 (1981).

141456 U.S. 742 (1982).

142 The challenged provisions of the Act were 15 U.S.C. $\S \S 3201-3211$ (1982); 16 U.S.C. $\S \S 824 a-3,2611-2613$ (1982).

14356 U.S. at $765-66$.

14 Id. at 769 .

145 Id. at 777 (O'Connor, J., dissenting).

${ }^{146}$ Id. at 775 . 
tional purposes. The Constitution contemplates "an indestructible Union, composed of indestructible States," a system in which both the State and National Governments retain a "separate and independent existence."

She rejected the Court's reasoning on two grounds. First, it contradicted the tenth amendment standard set out in National League of Cities. The challenged provisions regulated the states as states, as their commands were directed at state regulatory agencies. They also affected attributes of state sovereignty, since they directly affected the states' power to set their own policy agendas. Finally, the provisions directly impaired a state's ability to structure integral operations in areas of traditional state governmental functions by imposing restrictions on how state agencies regulating utilities could choose to discharge their responsibilities. ${ }^{148}$

Second, she denied the Court's finding that the "greater" federal power to preempt the field included the "lesser" power to impose these requirements upon states. In her view, the challenged provisions intruded further upon state powers than outright preemption would have. Preemption would establish a definite realm of proscribed state action and would leave states free to devote their resources and energies elsewhere. Moreover, it would not confuse the public in determining who was politically accountable for specific measures. ${ }^{149}$ She went on to review constitutional history in order to show the novelty of national action conducted through the exercise of "military or legislative power" mandating specific actions by state governments. ${ }^{150}$

${ }^{147}$ Id. at 777 (quoting Texas v. White, 74 U.S. (7 Wall.) 700, 725 (1869), overruled, Morgan v. United States, 113 U.S. 476 (1885); Lane County v. Oregon, 74 U.S. (7 Wall.) 71, $76(1869))$.

${ }^{148} 456$ U.S. at 778-81 (O'Connor, J., dissenting). The Court did not systematically apply the three criteria for judging whether a tenth amendment violation had occurred, but relied primarily on assimilating FERC to Hodel v. Virginia Surface Mining \& Reclamation Ass'n, Inc., 452 U.S. 264 (1981). See 456 U.S. at 764-71 (majority opinion). In Hodel, the federal law invited each state to submit a regulatory program for federal approval. The federal authority could either accept the state program or implement its own program. Accordingly, Justice O'Connor sought to distinguish Hodel, which she described as a true example of cooperative federalism, by emphasizing that the Hodel approach imposed smaller burdens on the states while maintaining clear lines of political accountability. Id. at 782-84 ( $O$ 'Connor, J., dissenting).

149 456 U.S. at 786-87 (O'Connor, J., dissenting).

${ }^{150} I d$. at 791-96. The majority disputed her historical analysis. Id. at 761-62 \& n.25 (majority opinion). Although Justice O'Connor's analysis in FERC rested on a procedural defense of state powers, she noted that in future cases the Court could offer a more substantive defense of state powers because it "has not explored fully the extent of 'traditional" state functions." Id. at 781 n.7 (O'Connor, J., dissenting). 
Justice Blackmun described Justice O'Connor's argument about preemption as "peculiar." He concluded that Congress "intended to defer to state prerogatives-and expertise-in declining to pre-empt the utilities field entirely. . . . Certainly, it is a curious type of federalism that encourages Congress to pre-empt a field entirely, when its preference is to let the States retain the primary regulatory role."151 In essence, he saw this set of measures as a permissible exercise in cooperative federalism. Justice O'Connor emphatically disagreed: “This Court's task is to enforce constitutional limits on congressional power, not to decide whether alternative courses would better serve state and federal interests." 152 Merely calling a program "cooperative federalism" cannot save it from violating the tenth amendment if it infringes on the most fundamental reserved powers of the states. ${ }^{153}$

Thus, Justice O'Connor rejected the Court's apparent confidence that federalism could rely on the cooperative attitude of Congress-a view that the Court would later carry to its extreme conclusion in Garcia. ${ }^{164}$ But her view rests, at least in this instance, on a different sort of confidence in Congress. She would prohibit Congress from embarking on this kind of exercise in cooperative federalism, leaving it with a stark choice between preemption and some less intrusive approach. It seems quite possible, however, that in most instances where Congress might have desired a FERC approach, it would have continued to eschew preemption and sought some cooperative alternative. ${ }^{155}$

${ }^{181}$ Id. at $765 \mathrm{n} .29$ (majority opinion).

${ }^{132}$ Id. at 786 (O'Connor, J., dissenting). In rejecting the argument that the greater federal power of preemption included the lesser power to demand specific action by state governments, she quoted former Attorney General Edward H. Levi's warning "against "lov[ing] the States to their demise." "Id. at 786 n.17 (quoting National Standards No-Fault Motor Vehicle Insurance Act: Hearings on S. 354 Before the Senate Comm. on Commerce, 94th Cong., 1st Sess. 503, 507 (1975)).

${ }^{163}$ She also rejected the possibility that the federal interest here could justify state submission to the federal action, a possible extra prong in the tenth amendment test that has never been invoked. "Whatever the ultimate content of that standard, it must refer not only to the weight of the asserted federal interest, but also to the necessity of vindicating that interest in a manner that intrudes upon state sovereignty." 456 U.S. at $781 \mathrm{n} .8$ (O'Connor, J., dissenting); cf. supra notes 93-105 and accompanying text (discussing her separation-of-powers approach to the issue of standing to gain judicial review of agency orders).

${ }^{154}$ See infra text accompanying note 159.

${ }^{155}$ Justice O'Connor's summary rejection of a tenth amendment challenge in Bell v. New Jersey, 103 S. Ct. 2187 (1983), is also of some interest. New Jersey challenged a federal statute that allowed the federal government to recover federal education funds misused by the state. The state had assumed this obligation as a condition on its receipt of federal funding. Treating the transaction like a voluntary contract, Justice O'Connor concluded 
At the root of this disagreement, to be sure, was a difference in views over the validity of the National League of Cities doctrine. This difference in views has emerged even more clearly now that the Court has overruled National League of Cities in Garcia $v$. San Antonio Metropolitan Transit Authority. ${ }^{186}$ Garcia presented the same issue that was presented in National League of Cities: whether state and local government officials could be covered by federal wage and hour laws. Justice Blackmun's opinion for the Court held that the federal laws did apply against state sovereign units, expressly overruling National League of Cities. ${ }^{157}$ The majority opinion in Garcia stressed the difficulty that courts had experienced in defining "traditional governmental functions" that would be immune from federal regulation, a difficulty that the Court thought to be so great as to make the doctrine unworkable. ${ }^{188}$ The Court also suggested that tenth amendment protection for states was redundant. The constitutional structure of the federal government-namely, representation by state in the Senate, state participation in the electoral college, and state power over the electoral requirements for its federal representatives-established "procedural safeguards" that have proven effective in preserving state interests. ${ }^{159}$

In line with the position she had elaborated at greater length in FERC, Justice O'Connor vehemently dissented. While accepting that Congress had been given broad and flexible powers to regulate commerce, she nonetheless stated that the "true 'essence' of federalism is that the States as States have legitimate interests which the National Government is bound to respect even though its laws are supreme."180 In her view, this core of federalism means at least two things. First, the great scope of congressional powers most certainly does not include power to trample state sovereignty: "It is not enough that the 'end be legitimate'; the means to that end cho-

that the measure did not interfere with state sovereignty. But she noted that the state had not challenged "the program itself as intruding unduly on its sovereignty." $I d$. at 2197 . Thus she identified, but left aside for the moment, the issue of whether some federally funded programs may be drafted coercively enough to infringe state sovereignty-in short, that the tenth amendment might limit the congressional spending power.

105 S. Ct. 1005 (1985).

167 Id. at $1007,1020$.

182 Id. at 1010-16. Ironically, this same prong of the National League of Cities test that Justice O'Connor pointed to in FERC as providing an avenue for possible expansion of tenth amendment limitations on congressional powers, see supra note 150 , served as the primary basis for the Court's rejection of that doctrine.

$138105 \mathrm{~S}$. Ct. at 1017-20.

${ }^{180}$ Id. at 1034 (O'Connor, J., dissenting) (emphasis in original). 
sen by Congress must not contravene the spirit of the Constitution." 161 Second, the complexities of maintaining a federal structure within a nation where technology and societal change have vastly eroded the significance of state boundaries must be reflected in the Court's approach. National League of Cities had held out the promise of developing a blueprint for state relations with the federal government. Although that promise remains unfulfilled, the difficulties of defining the boundaries of tenth amendment doctrine do not justify the Court in evading the task. ${ }^{162}$ But even if $\mathrm{Na}$ tional League of Cities were to be rejected, then a more appropriate resolution may lie "in weighing state autonomy as a factor in the balance when interpreting the means by which Congress can exercise its authority on the States as States."163 Thus, Justice O'Connor argued for adherence to National League of Cities despite its apparent practical difficulties; and in the alternative, she flatly rejected the Court's reliance on the structure of the federal political process as the basic safeguard of state interests.

2. Federal Preemption of State Legislation. In addition to the protection she would offer the states under the tenth amendment, Justice O'Connor appears determined to construe the reach of federal statutes narrowly when necessary to minimize the preemption of state legislative power. Her dissent in Southland Corp. $v$. Keating ${ }^{164}$ demonstrates this determination. At issue was a possible clash between the Federal Arbitration Act ${ }^{165}$ and a California law. ${ }^{166}$ The California Supreme Court had held that claims arising under the state law were not arbitrable, but must be brought in state court. In contrast, the federal law broadly endorsed arbitration as a method of resolving civil claims. The Court concluded that the state law, so construed, violated the supremacy clause. ${ }^{167}$ The federal statute was held to be a substantive law, promulgated under Congress's power to regulate interstate commerce. "In enacting $\S 2$ of the federal Act, Congress declared a national policy favoring arbitration and withdrew the power of the states to require a judicial forum for the resolution of claims which the con-

${ }^{161}$ Id. at 1036 (quoting McCulloch v. Maryland, 17 U.S. (4 Wheat.) 316, 421 (1819)).

$162105 \mathrm{~S}$. Ct. at 1037-38 (O'Connor, J., dissenting). No doubt one of the major sources of this problem has been the Court's steadfast refusal to apply its tenth amendment doctrine with any bite in cases after National League of Cities.

${ }^{163}$ Id. at 1037 .

104 S. Ct. 852 (1984).

1659 U.S.C. $\$ \S 1-14$ (1982).

${ }^{168}$ Franchise Investment Law, CaL. CoRP. Code $\S 31,512$ (West 1977).

167104 S. Ct. at 861. 
tracting parties agreed to resolve by arbitration." 168

Justice O'Connor offered a very different interpretation of congressional intent. She characterized the federal law as procedural in nature and as intended to apply only in federal courts. Thus, it did not preempt a state law applicable only in state courts. ${ }^{169}$

Although Southland could perhaps be viewed as no more than a disagreement about congressional intent, Justice O'Connor's desire to narrow the scope of federal preemption is clear enough. In Brown v. Hotel \& Restaurant Employees International Union Local 54, ${ }^{170}$ she spoke for the Court in finding no conflict between a New Jersey law regulating the qualifications of casino industry union officials and portions of the National Labor Relations Act. ${ }^{171}$ As Justice White pointed out in dissent, however, the state law did more than limit who could serve as union officials; it imposed sanctions on offending unions themselves, including prohibitions on receiving dues. In his view, this prohibition was in direct conflict, as a matter of law, with federally protected rights of employees. ${ }^{172}$ Justice O'Connor, for the Court, remanded for a factual determination of whether the prohibition on collecting dues incapacitated the local from carrying out the responsibilities of a collective bargaining agent, but she was unwilling to find preemption as a matter of law. ${ }^{173}$ Indeed, in Fidelity Federal Savings \& Loan Association v. de la Cuesta, ${ }^{174}$ where she agreed with the Court's holding of preemption, she wrote a separate concurrence simply to emphasize that the preemption power exercised in that case was not "limitless" and to point out several kinds of local laws that could not be supplanted. ${ }^{175}$

${ }^{168}$ Id. at 858 .

168 Id. at 865-68 (O'Connor, J., dissenting). She also argued that if the federal statute did create any substantive rights, the state courts should still be permitted to develop their own procedures for enforcing those rights. Id. at 868-69 \& n.20. The Court apparently agreed. Id. at 861 n.10 (majority opinion).

270104 S. Ct. 3179 (1984).

${ }^{171}$ National Labor Relations Act § 7, 29 U.S.C. § 157 (1982). The state law was the Casino Control Act, N.J. STAT. ANN. \$§ 5:12-1 to -152 (West Supp. 1984-1985).

${ }^{172} 104$ S. Ct. at 3192-93 (White, J., dissenting).

${ }^{173}$ Id. at 3191-92; see also Rice v. Rehner, 103 S. Ct. 3291 (1983) (O'Connor, J.) (holding that federal law authorized, rather than preempted, state regulation of Indian liquor transactions).

174458 U.S. 141 (1982). The preemption issue here was slightly different from that in Brown because it concerned the extent to which a federal agency had the statutory power to issue regulations that preempted conflicting state judicial doctrine. The differences, however, were unimportant.

${ }^{175}$ Id. at 171-72 (O'Connor, J., concurring); cf. Block v. North Dakota, 461 U.S. 273, 


\section{B. The Federal and State Judiciaries}

Justice O'Connor's view of federalism also informs her outlook on how the federal courts should interact with their state counterparts. She does not view state courts as errant children in need of parental guidance by the federal courts. Rather, both the federal and state judiciaries play equally important roles as partners in the federal scheme and each deserves the other's respect.

1. Exhaustion of State Remedies. Justice O'Connor's willingness to grant considerable independence and responsibility to state courts is most evident in her desire to prevent the federal courts from reviewing cases where state remedies have not been completely exhausted. This approach bolsters the role of state courts in two ways. First, it emphasizes that state courts are on a par with federal courts in their ability to treat all the issues that arise in a given case. Second, it ensures that the separate judicial machinery of the various states, once engaged, must be used to the fullest before any federal court intervention is permissible.

Justice O'Connor's support for requiring exhaustion of state remedies has shown up primarily in cases involving federal habeas corpus petitions. ${ }^{176}$ In Rose $v$. Lundy, ${ }^{177}$ the defendant had been convicted of rape and other offenses. After unsuccessfully seeking relief from the conviction in state court, he filed a petition for a writ of habeas corpus in federal district court. Under federal statute, ${ }^{178}$ a state prisoner's application for the federal writ based on an alleged federal constitutional violation will not be granted unless the applicant has exhausted the remedies that are available in state courts. In this case, the defendant's petition included two claims that had been exhausted in state court and two claims that had not. The language of the statute did not indicate how strictly the exhaustion requirement should apply to such a "mixed" petition. Without assessing the merits of the unexhausted claims, the district court granted the writ. ${ }^{178}$

293-99 (1983) (O'Connor, J., dissenting) (limitations period in federal quiet-title statute does not bar a sovereign state); Toll v. Moreno, 458 U.S. 1, 24-25 (1982) (O'Connor, J., concurring in part and dissenting in part) (federal immigration statute only prohibits state from charging out-of-state tuition to nonimmigrant alien who is exempted by federal law from both federal and state taxes, not to one who is exempt from federal taxes only).

${ }_{178}$ But it arises in other areas as well. See, e.g., Patsy v. Board of Regents, 457 U.S. 496 (1982) (O'Connor, J., concurring) (urging Congress to reconsider statutory provisions that do not require exhaustion of state remedies in federal civil rights actions).

177455 U.S. 509 (1982).

17828 U.S.C. § 2254 (b)-(c) (1982).

178455 U.S. at 511-13. 
The Supreme Court reversed. Justice O'Connor's majority opinion held, as a matter of statutory interpretation, that a "total exhaustion" rule was applicable here, requiring district courts to dismiss habeas corpus petitions that contain both exhausted and unexhausted claims. If rigorously enforced, this rule "will encourage state prisoners to seek full relief first from the state courts, thus giving those courts the first opportunity to review all claims of constitutional error."180 This result serves the dual purposes of the statute: "to protect the state courts' role in the enforcement of federal law and prevent disruption of state judicial proceedings."181

The most telling part of Justice O'Connor's opinion, however, and the only part that failed to carry a majority, was her suggestion in dicta that a prisoner should be required to present all claims together, in the same petition for the federal writ, and to do so only when they have all been exhausted. If he does not, the federal courts should be permitted to decline to hear additional claims that become exhausted later. "Thus a prisoner who decides to proceed only with his exhausted claims and deliberately sets aside his unexhausted claims risks dismissal of subsequent federal petitions."182 Under this approach, in order to maximize his chances of obtaining the federal writ, a prisoner must first exhaust state remedies for all the claims he might ever wish to present. In other words, Justice O'Connor seems to regard the shift from seeking state remedies to seeking federal relief as more akin to crossing the Rubicon than it is to crossing the street to another courtroom. As a practical matter, her view apparently would lead to a much greater insulation of state court proceedings from the potential intrusions of the federal writ.

The most direct criticism of this approach was contained in Justice Stevens' dissent. He argued that the writ of habeas corpus is "a fundamental guarantee of liberty," and therefore its availability "should depend primarily on the character of the alleged constitutional violation and not on the procedural history underlying the claim."183 This view is antithetical to Justice O'Connor's approach, for it suggests that federal habeas relief provides a remedy that is superior to any relief that can be obtained from a state court. $^{\mathbf{1 8 4}}$ Thus, in certain serious instances, federal relief would be

\footnotetext{
180 Id. at $518-19$.

182 Id. at 518.

132 Id. at 521 .

18s Id. at 546, 548 (Stevens, J., dissenting).

184 Justice O'Connor's position confronted the unspoken but pervasive assumption that
} 
a justifiable intrusion into state proceedings without regard to the exhaustion doctrine and its niceties. In Justice O'Connor's view, no such presumption is justified: both state and federal courts offer habeas remedies, both remedies are available on the same grounds and must be presumed equally effective in achieving the same goal, and both can be explored in turn. Yet they should be explored in turn in a manner that minimizes federal interference with state judicial systems.

This disagreement between the two Justices was also at the heart of Engle v. Isaac, ${ }^{185}$ decided only one month after Rose. Although the case did not directly address the exhaustion doctrine, it raised similar issues. ${ }^{188}$ At issue in Engle was whether the petitioner in a federal habeas proceeding could raise a constitutional claim after he had forfeited that claim in the state courts by failing to comply with a state procedural rule. Justice O'Connor's opinion, for a bare majority, disallowed the claim. Although the Court was merely reaffirming its earlier holding in Wainwright $v$. Sykes, ${ }^{187}$ she took the occasion to stress that the federal writ

imposes special costs on our federal system. The States possess primary authority for defining and enforcing the criminal law. In criminal trials they also hold the initial responsibility for vindicating constitutional rights. Federal intrusions into state criminal trials frustrate both the States' sovereign power to punish offenders and their good-faith attempts to honor constitutional rights. ${ }^{188}$

In a separate opinion, Justice Stevens again criticized the

the federal courts stand as special shields of individual liberties, in contrast to the state courts, which are thought less solicitous of criminal defendants (perhaps because of a more immediate concern for public safety). She flatly rejects this view of state courts, see infra note 188 and accompanying text, but her pronounced sympathy with government interests would also be compatible with accepting this view and defending the state courts precisely because they are more inclined toward protecting the public. See infra notes 208-56 and accompanying text.

${ }^{185} 456$ U.S. 107 (1982).

186 Justice Brennan argued that Isaac's petition for the writ did raise the same exhaustion issue decided in Rose. Id. at 140-41 (Brennan, J., dissenting). Justice O'Connor construed the petition to present no unexhausted claim. See id. at 123 n.25 (majority opinion).

${ }^{187} 433$ U.S. 72, 86-87 (1977) (holding that defendant's failure to follow state procedural requirements constituted an "independent and adequate state procedural ground" precluding the Court's review).

${ }^{188} 456$ U.S. at 128 (majority opinion); see also McKaskle v. Vela, 104 S. Ct. 736, 738 (1984) (O'Connor, J., dissenting from denial of certiorari) (arguing that the exhaustion rule prevents federal courts from reviewing federal habeas petitions containing allegations of error that were not raised in state court but are integral to the constitutional challenge). 
Court for its "preoccupation with procedural hurdles."189 His criticism here was muted, however, because the Court's opinion had conceded that the federalism principles it relied upon could be overridden by "the imperative of correcting a fundamentally unjust incarceration." 190 This concession by Justice O'Connor invites comparison with her opinion in Rose. In Rose, she indicated an unwillingness to subordinate the exhaustion doctrine, and the important federalism principles that it effectuates, to the federal judiciary's self-defined role as the guarantor of liberty. Yet here she suggested that there may be occasions where state procedural rules must be subordinated to federal judicial power. This concession illustrates the rough and perhaps unsettled boundaries to Justice O'Connor's view of federalism. Although she seeks adherence to stricter procedural principles in the relations between state and federal courts, she accepts the subordination of state powers to important federal concerns.

2. Adequate and Independent State Grounds. Another matter bearing on relations between the federal and state judiciaries comprises those instances in which the Supreme Court is asked to decline review of state court decisions that are claimed to rest on an "adequate and independent state ground." When that claim is correct, the Court declines to review the state court's decision because its decision could not alter that of the state court and thus would be advisory. ${ }^{191}$ In three cases, Justice O'Connor has given especially careful attention to such claims. ${ }^{122}$ Although she finally agreed that jurisdiction was proper in all three cases, one of them is of particular interest.

In Michigan $v$. Long, ${ }^{193}$ Justice O'Connor set out a new approach to determining whether a decision rests on an "adequate and independent state ground." The Michigan Supreme Court had ordered evidence in a criminal trial suppressed because it was the product of an illegal search. In its decision, the Michigan court mentioned provisions of both the federal and state constitutions. ${ }^{194}$

188456 U.S. at 136 (Stevens, J., concurring in part and dissenting in part).

100 Id. at 135.

101 See Herb v. Pitcairn, 324 U.S. 117, 125-26 (1945), overruled on other grounds, Michigan v. Long, $103 \mathrm{~S}$. Ct. 3469 (1983).

192 The two cases not examined here are Hathorn v. Lovorn, 457 U.S. 255 (1982) (taking jurisdiction despite failure to comply with a state procedural rule), and United States v. Frady, 456 U.S. 152 (1982) (taking jurisdiction against an argument that a local District of Columbia law resolved the matter).

193103 S. Ct. 3469 (1983).

194 Id. at 3474 n. 3 (citing the state court opinion). 
The defendant argued that because the state constitution afforded greater protection from search than the fourth amendment, it provided an adequate and independent state ground for the decision, and therefore the Supreme Court had no jurisdiction to review the case.

Justice O'Connor, writing for a majority of the Court, rejected this argument and took jurisdiction. She concluded from the contents of the state court's analysis that it had rested its decision primarily on federal law, despite its brief references to the state constitution, and that reliance on federal law should be presumed "in the absence of a plain statement that the decision below rested on an adequate and independent state ground."

In reaching this result, she offered a new treatment of the jurisdictional issue to replace what she felt were the Court's prior inconsistent and unsatisfactory approaches. In particular, she opposed the practices of having the Supreme Court either examine state law itself or require clarification from the state courts. The former alternative required the Court to decide unfamiliar issues of state law going beyond the opinion under review; the latter would impose significant burdens on state courts to settle questions of federal jurisdiction, which were irrelevant to the statecourt determination and only arose after the case left the state court system. ${ }^{198}$ This left two possible options: a rebuttable presumption of federal jurisdiction or of its absence. Her solution was to presume federal jurisdiction in unclear cases in order to protect uniformity in federal law, but to allow the state courts to overcome this presumption by including a statement to the contrary. This provides an easy and clear guideline for both federal and state courts to follow. "If the state court decision indicates clearly and expressly that it is alternatively based on bona fide separate, adequate, and independent grounds, we, of course, will not undertake to review the decision." 197

This new standard attracted immediate criticism on the ground that it expanded federal judicial power over the state courts. In a separate opinion, Justice Stevens argued for a presumption against jurisdiction in unclear cases, contending that the Court's approach failed both to respect state courts and to exercise judicial restraint, which "allows other decisional bodies to have the last word in legal interpretation until it is truly necessary for this

195 Id. at 3478 .

196 Id. at $3475-76$.

197 Id. at 3476 . 
Court to intervene."198

This criticism sheds interesting light on Justice O'Connor's approach to federalism. She did not shrink from expanding the occasions for federal court review of state court judgments. ${ }^{199} \mathrm{Her}$ opinion in Long evinced no desire to permit the last word in legal interpretation to lie with the state courts where it might interfere with the uniformity of federal law. ${ }^{200}$ Instead, her chief concern in Long was to keep the manner of determining any "adequate and independent state ground" from becoming too intrusive upon state judicial functions. As she explained it, her approach "will provide state judges with a clearer opportunity to develop state jurisprudence unimpeded by federal interference, and yet will preserve the integrity of federal law." ${ }^{201}$ In short, the mechanisms of state government are to be protected against federal intrusions, but not beyond the proper sphere of state governmental functions. ${ }^{202}$

108 Id. at 3490 (Stevens, J., dissenting). Justice Blackmun also briefly indicated his disagreement with this ruling. Id. at 3483 (Blackmun, J., concurring in part and dissenting in part). Justice Stevens further criticized the Court for ignoring the principle of stare decisis, since it had substituted a new presumption in favor of federal jurisdiction in place of the opposite rule. Id. at 3489-90 (Stevens, J., dissenting). But the question of whether to return to an older, rejected line of precedent involves concerns similar to those identified by Justice O'Connor in City of Akron v. Akron Center for Reproductive Health, Inc., 462 U.S. 416, 452-61 (1983) (O'Connor, J., dissenting) (discussed supra notes 31-49 and accompanying text), where she had urged the rejection of precedent. Presumably the older line of precedent had already been abandoned because the Court found it unsatisfactory.

${ }^{100}$ It may be noted in passing, however, that the application of the bare language of her approach, without more, might not lead to any expansion of federal power to review state decisions, depending on how deferential the Court would be in reviewing the state court's statement that its decision rested on adequate and independent grounds. If a bare statement would be considered sufficient, then state courts could easily insulate their decisions from federal scrutiny. Cf. Hawaii Hous. Auth. v. Midkiff, 104 S. Ct. 2321, 2329-30 (1984) (O'Connor, J.) (giving extensive deference to legislative statements).

${ }^{200}$ Cf. supra note 49 (discussing Justice O'Connor's conviction that the Court should exercise strong guiding power within the judicial system). This point is reinforced by considering an interesting federalism issue raised by Justice Stevens in Long. He argued that the Court should not bother to review cases like this one, where the complaining party "is an officer of the state itself, who asks us to rule that the state court interpreted federal rights too broadly and 'overprotected' the citizen." $103 \mathrm{~S}$. Ct. at 3490 (Stevens, J., dissenting). If the state of Michigan were a separate sovereign nation, its interpretation would be of no concern to the United States, as no individual's rights were infringed. Id. at 3490-92. Justice O'Connor showed no interest in avoiding review of a state court's generous interpretation of federal constitutional law, although she has agreed with the view that states may provide greater protections in their own criminal laws than the Constitution requires. See California v. Ramos, 103 S. Ct. 3446, 3459-60 (1983) (O'Connor, J.).

${ }^{201} 103 \mathrm{~S}$. Ct. at 3476 (majority opinion).

202 This position is reflected in a speech that Justice O'Connor delivered at the College of William and Mary while she was still on the Arizona bench. Deploring the current state of affairs, in which "state appellate court judges occasionally become so frustrated with the extent of federal court intervention that they simply abdicate in favor of the federal juris- 
Although Long thus seems compatible with Justice O'Connor's views on federalism, it also bears comparison with the habeas cases in light of its substantive context. The bulk of these "adequate and independent state ground" cases come to the Court, as did Long, in a procedural setting in which one party is seeking to narrow the lower court's construction of constitutional provisions. ${ }^{203}$ In other words, the Court usually is being asked to overturn a judgment below that was particularly protective of individual rights. Justice O'Connor's willingness to erect a presumption in favor of federal jurisdiction in these cases may simply indicate her willingness to have the Court examine and possibly overturn these typically "liberal" results. ${ }^{204}$ In contrast, the habeas cases involve a party who is asking the federal courts for more generous treatment than was afforded in prior proceedings. Her position in these cases, which strongly defends the exhaustion doctrine, makes it more difficult for the federal courts to intervene and grant a more "liberal" reading of constitutional provisions. Thus, her approach here is in harmony with Long in the sense that both serve to discourage the courts from reaching results that are particularly solicitous of individual rights. ${ }^{205}$

diction," she stated that "we should strive to make both the federal and the state [judicial] systems strong, independent, and viable." O'Connor, Trends in the Relationship Between the Federal and State Courts from the Perspective of a State Court Judge, 22 WM. \& MARY L. REv. 801, 801, 814 (1981).

${ }^{203}$ See, e.g., Delaware v. Prouse, 440 U.S. 648 (1979); Herb v. Pitcairn, 324 U.S. 117 (1945), overruled, Michigan v. Long, 103 S. Ct. 3469 (1983).

204 Moreover, Long's "grant" of jurisdiction to the Court in these ambiguous cases can have substantive federalism results because it enables the Court to review state-court criminal judgments that may rely on an overly broad understanding of federal constitutional protections. Long itself is typical of this kind of case. The state court may have reversed the defendant's conviction because it mistakenly thought that the federal Constitution compelled the result. Long authorizes the Supreme Court to reach that constitutional question, to articulate the (possibly more limited) scope of the constitutional protection, and to allow the state court a second chance to rule on the state constitutional issue free of possible misconceptions about controlling federal law. To the extent that this approach gives "mistaken" state courts more freedom in determining the scope of state protections, it results in less federalization of state criminal law. This substantive consequence of Long is consistent with Justice O'Connor's concern for federalism.

${ }^{205}$ In a recent speech, Justice O'Connor herself coupled the habeas relief cases with "adequate and independent state grounds" cases. See O'Connor, Our Judicial Federalism, 35 CASE W. REs. L. Rev. 1 (1984-1985). For further discussion of Justice O'Connor's approach to more substantive constitutional provisions, see infra notes 208-56 and accompanying text. 


\section{The Calculus of Interests: Private Rights and the AUTHORITY TO GOVERN}

As emphasized earlier, ${ }^{206}$ Justice O'Connor seeks to restrain judicial intervention into the operations of other branches of government. In the more "substantive" areas of constitutional law, that approach often leads her to defer to government interests in the course of weighing those interests against the rights claimed by individuals. ${ }^{207}$ Of course, the causal connection may also run in the opposite direction: the belief that individual rights and protections have been interpreted too broadly, and that the needs of government deserve more respect than they currently evoke, would point to more sparing use of the judicial power. The precise nature of the causal relation in Justice O'Connor's jurisprudence is less important than the harmony between the two positions.

Nonetheless, this second interpretation is useful in understanding the direction of Justice O'Connor's jurisprudence on issues of constitutional protections. These issues are typically approached through the language of "rights," and the framework for debate about constitutional protections rests on a belief in the priority of individual liberties. According to this view, good government is limited government, instituted by the consent of the governed, and entered into only to secure the continued preservation of life and liberty; it is therefore necessary for the governed always to be vigilant against uses of government power that encroach on private spheres of liberty. Constitutional protection of individual rights institutionalizes this suspicion of government power. Yet, it is possible to view these issues from a perspective that is more respectful of the government's authority. Government is instituted in order to preserve life and liberty; without vigorous government, individuals would be vulnerable to criminal behavior that renders them less secure in their persons and property, and to political behavior that threatens their fundamental freedoms. Good government, although limited in its powers, seeks to advance the most essential collective interests of citizens in a healthy political community. Government power is not simply destructive of liberty; indeed, government is an indispensable guardian of life and liberty. On this view, a reasonable approach to constitutional protections must balance the collective interest in strong government against

208 See supra notes 3-137 and accompanying text.

${ }^{207}$ For a discussion of Justice O'Connor's role in forging a "majoritarian" Court, see Stone, O.T. 1983 and the Era of Aggressive Majoritarianism: A Court in Transition, 19 GA. L. REv. 15, 23 (1984). 
rightful fear of the abuse of government power. The controversial issues in substantive constitutional law involve the proper striking of this balance. On these issues, Justice O'Connor's jurisprudence is marked by an especially high regard for the beneficial results of government power.

This part of the comment begins by considering three issues in the field of criminal procedure that directly illustrate Justice O'Connor's approach. The focus then turns to subjects that do not so clearly reflect the same outlook: first amendment rights, where Justice O'Connor's approach has so far remained embryonic, and equal protection doctrine, where her one major opinion stands in stark contrast to her usual position of deference to government interests.

\section{A. Deference to Government Interests: Criminal Procedure}

Justice O'Connor has written a number of opinions concerning constitutional protections within the criminal justice process. This section of the comment considers three subjects-privacy rights in the law-enforcement context, the double jeopardy clause, and the exclusionary rule - that are representative of her general approach to these issues. This approach comprises three major elements. First, she confines the constitutional protection to what she views as the narrow purposes that underlie it. ${ }^{208}$ Second, she identifies the social costs of protecting the individual in terms of interference with the achievement of legitimate government objectives. Third, she often balances the importance of the individual's interest against the costs to society in a manner that greatly curtails the scope of the individual protection while furthering the state's ability to enforce its criminal laws. The dominant theme is her great respect for government interests in effective law enforcement. ${ }^{209}$

1. Privacy Rights and Law Enforcement. In several instances, Justice O'Connor has taken a stringent position on the extent to which protections for individual privacy and security can be allowed to hinder the processes of law enforcement. The distinctive feature of these cases is their relation to express language

${ }^{208}$ Her approach to first amendment issues is occasionally similar. See infra notes 25786 and accompanying text.

${ }^{209}$ Justice O'Connor has written a few opinions that were somewhat more protective of individual rights. See, e.g., Bearden v. Georgia, 461 U.S. 660 (1983) (reversing and remanding for alternative sentencing procedures); Kolender v. Lawson, 461 U.S. 352 (1983) (invalidating a criminal-loitering statute for vagueness); Eddings v. Oklahoma, 455 U.S. 104, 117 (1982) (O'Connor, J., concurring) (reversing and remanding for alternative sentencing procedures). 
in the fourth amendment limiting the government's power to search and seize individual persons and property. ${ }^{210}$ As a general rule, Justice O'Connor has interpreted the fourth amendment in a manner that is quite favorable to the government's interests in law enforcement.

Justice O'Connor's exposition of the fourth amendment began with her majority opinion in United States $v$. Place. ${ }^{211}$ At issue was whether the fourth amendment prohibited warrantless searches and seizures of personal property on a lower threshold of suspicion of criminal activity than probable cause. Justice O'Connor's decision expanded the circumstances under which lawenforcement authorities could undertake "reasonable" searches and seizures without having to meet the standard of probable cause.

In Place, the defendant had been convicted for possession of narcotics after his motion to suppress certain evidence was denied. The contested evidence had been obtained after the defendant was stopped and questioned at New York's LaGuardia Airport. When he refused consent to a search of his suitcases, the luggage was seized and taken to Kennedy Airport, where, ninety minutes later, it was subjected to a "sniff test" by a narcotics-detection dog. After the test gave a positive result, the government agents obtained a warrant to search one of the bags and found a large quantity of cocaine. ${ }^{212}$

The Court ruled that evidence so obtained must be suppressed. Justice O'Connor's opinion held that this ninety-minute detention of the defendant's luggage was an unreasonable seizure of personal property under the fourth amendment. The length of time alone made the seizure unreasonable because it constituted too great an intrusion on the defendant's right to be secure in his personal effects. ${ }^{213}$

210 Similarly, Justice O'Connor has expressed concern that the uncertain reach of individual privacy zones, which are acknowledged to be under the implied protection of the Constitution, must not be permitted to undermine government's power to make legitimate demands on its citizens or to take actions that benefit the public as a whole. See City of Akron v. Akron Center for Reproductive Health, Inc., 462 U.S. 416, 452 (1983) (O'Connor, J., dissenting) (discussed supra notes $31-49$ and accompanying text); cf. Brown v. Socialist Workers '74 Campaign Comm., 459 U.S. 87, 110-12 (1982) (O'Connor, J., concurring in part and dissenting in part) (offering a narrow view of the first amendment's protection for the privacy of one's political beliefs) (discussed infra notes 274-80 and accompanying text).

211103 S. Ct. 2637 (1983).

212 Id. at $2639-40$.

${ }^{213}$ Id. at 2645-46. Justice O'Connor also mentioned several other factors that had exacerbated the intrusiveness of this seizure, but she refused to specify the outside time limit for 
In reaching this conclusion, however, Justice O'Connor undertook a general discussion of the fourth amendment's requirements for upholding warrantless seizures of personal property. She expressly rejected the notion that all warrantless seizures of personal property on less than probable cause were constitutionally prohibited. ${ }^{214}$ Citing Terry $v$. Ohio ${ }^{215}$ for the proposition that certain limited searches may be made without probable cause, she found that some seizures might also be so minimal as not to require probable cause:

We must balance the nature and quality of the intrusion on the individual's Fourth Amendment interests against the importance of the governmental interests alleged to justify the intrusion. When the nature and extent of the detention are minimally intrusive of the individual's Fourth Amendment interests, the opposing law enforcement interests can support a seizure based on less than probable cause. ${ }^{216}$

She also reasoned that, in light of the "inherently transient nature of drug courier activity at airports," the state's need to seize and investigate luggage there outweighs a brief intrusion on fourth amendment interests. ${ }^{217}$

Justice O'Connor also considered whether a "sniff test" constituted a "search" within the meaning of the fourth amendment. She found that it did not. Because the test did not involve opening the luggage and would only indicate the presence or absence of contraband narcotics, the defendant's privacy interests in the contents of his personal luggage, which are protected by the fourth amendment, were only minimally affected by the "sniff test."218 Mirroring the thrust of the opinion as a whole, this dictum was intended to remove uncertainty about the constitutionality of a very effective law-enforcement technique. ${ }^{219}$

Justice Brennan's concurring opinion protested against the Court's niggardly view of fourth amendment protections. He espe-

a permissible stop. Id. \& n.10.

214 Id. at $2641-42$.

215392 U.S. 1 (1968).

$216103 \mathrm{~S}$. Ct. at 2642 .

217 Id. at 2643.

${ }^{218} I d$. at 2644-45. Justices Brennan and Blackmun criticized her for reaching this issue, which was not briefed for the Court. They also suggested other possible resolutions of the issue. Id. at 2651 (Brennan, J., concurring); id. at 2653 (Blackmun, J., concurring).

219 Cf. United States v. Karo, 104 S. Ct. 3296, 3307 (1984) (O'Connor, J., concurring) (suggesting a narrower view of fourth amendment privacy zones that would remove any constitutional obstacle to certain uses of electronic beepers as aids to law enforcement). 
cially stressed the limited applicability of the Terry exception to the probable-cause requirement. ${ }^{220}$ Terry and its progeny had approved, on less than probable cause, a brief investigative stop of a person coupled with a limited or "pat down" weapons search, where the urgency of the circumstances prevent warrant procedures from being followed. ${ }^{221}$ That approach is justified as helping police officers to detect and prevent crime (the stop) and assuring reasonable safety to the officers themselves (the search). ${ }^{222} \mathrm{By}$ emphasizing the law-enforcement rationale, the Court in Place was willing to apply this exception to uphold a seizure of personal property entirely apart from seizure of the person, where no immediate threat to anyone's safety had been alleged. ${ }^{223}$ But a seizure of property implicates the person's fourth amendment interest in retaining possession of personal property-an interest that is distinct from the interest in personal security and privacy implicated by a personal stop. According to Justice Brennan, nothing in the Terry line of cases authorized intrusion on this distinct interest, independent of a personal stop, in the absence of probable cause. The result, he argued, is "a radical departure from settled Fourth Amendment principles." 224 The remoteness of this result from the original Terry holding is apparent when one notes that seizure of a

${ }^{220} 103 \mathrm{~S}$. Ct. at 2646-51 (Brennan, J., concurring).

${ }^{221}$ See Terry, 392 U.S. at 30 . The investigative stop contemplated in Terry was explicitly approved in Adams v. Williams, 407 U.S. 143, 145-46 (1972). For an ordinary application of Terry principles, see, e.g., State v. Brooks, 127 Ariz. 130, 136, 618 P.2d 624, 630 (Ct. App. 1980) (O'Connor, J.) (denying a motion to suppress evidence obtained in an investigative stop).

${ }^{222}$ Terry, 392 U.S. at $22=24$. The search itself was only justified under the safety rationale. Id. at 27.

${ }^{223}$ Justice Brennan's account thus separated the initial stop of the defendant for questioning from the "independent dispossession of his personal effects." 103 S. Ct. at 2650 (Brennan, J., concurring). Certainly the two actions were much more independent here than where a person is stopped and frisked for weapons.

${ }^{224}$ Id. at 2649. Less than one month after Place, Justice O'Connor wrote the Court's decision in Michigan v. Long, $103 \mathrm{~S}$. Ct. 3469 (1983), provoking almost identical disagreement from Justice Brennan. The substantive issue in Long was whether a protective search of the passenger compartment of a motor vehicle, during a lawful investigatory stop of the vehicle's occupant, was reasonable under Terry principles. The Court held that the search was reasonable. This result was not surprising after Place, since Long was even more analogous to Terry. The central issue was simply whether the justifications offered in Terry for frisking the suspect's person could be extended to a search of the immediate area, including the suspect's vehicle. Emphasizing the need to assure reasonable safety to law-enforcement officials, and the dangers present in this factual situation, Justice O'Connor found that the need to search outweighed the invasion of the driver's privacy interests. Id. at 3478-82. But Justice Brennan contended that "the Court takes a long step today toward 'balancing' into oblivion the protections the Fourth Amendment affords." Id. at 3488 (Brennan, J., dissenting). 
thing, independent of the stop of the person, would rarely involve the safety concerns that were an integral part of the Terry rationale. 225

Justice O'Connor's concurring opinion in Hua'son v. Palmer ${ }^{228}$ casts further light on her approach to search-and-seizure issues. Here, she rejected a balancing approach in favor of a blanket authorization of prison-cell searches and seizures.

[T] he Government's compelling interest in prison safety, together with the necessarily ad hoc judgments required of prison officials, make prison cell searches and seizures appropriate for categorical treatment. ... The fact of arrest and incarceration abates all legitimate Fourth Amendment privacy and possessory interests in personal effects, . . . and therefore all searches and seizures of the contents of an inmate's cell are reasonable. ${ }^{227}$

This statement was startling because in this instance the inmate had some personal property taken (and indeed destroyed) that was not contraband, and the property may have been seized merely to harass the inmate-one of the hardest imaginable situations for the application of a blanket rule in favor of prison searches and seizures. ${ }^{228}$

Justice O'Connor's view of fourth amendment protections is made quite clear by comparing her opinion in.Place with her con-

${ }^{225}$ Justice O'Connor's opinion also expanded Terry in a manner not mentioned by Justice Brennan. Terry and Adams v. Williams, 407 U.S. 143 (1972), approved a seizure of a person for purely investigative purposes; Place simply extends this reasoning to seizures of property. This extension, however, ignores an important difference between persons and property. The kind of investigation that police can conduct of a thing separately seized is much more like a search than that conducted of a person incident to a Terry stop. A person may be stopped and questioned, but he cannot be compelled during the investigation to give information incriminating himself. Seizure of a thing, independent of the stop of the person, is unlikely to be for any other reason than some type of quasi-search. For example, the agents in Place seized the luggage for the purpose of subjecting it to a sniff test; although Place concluded that the test did not constitute a search, it is actually closer to a search than the questioning of a suspect, who can maintain silence. Thus, a detention of personal property is a very different kind of stop than that approved in Adams. Terry balancing is used in Place to justify a detention, the primary focus of which is not mere questioning but a quasi-search for evidence of a crime. The result is thus a long way from the brief stop of a person and limited weapons search in Terry, on which Justice O'Connor chiefly relied.

${ }^{228} 104$ S. Ct. 3194 (1984).

${ }^{227}$ Id. at 3206 (O'Connor, J., concurring). This conclusory statement expressed her agreement with the Court's fuller analysis. See id. at 3200-02.

${ }^{228}$ Id. at 3196-97. These circumstances prompted Justice Stevens to ask: "Is the Court correct in its perception that 'society' is not prepared to recognize any privacy or possessory interest of the prison inmate-no matter how remote the threat to prison security may be?" Id. at 3208 (Stevens, J., dissenting) (emphasis in original). 
currence in Hudson. In Place, she had employed a balancing approach in limiting the reach of the stringent probable cause requirement. In Hudson, however, she joined the Court in employing exactly the opposite judicial technique. Thus, although she often assesses criminal procedural protections by balancing state and individual interests, a balancing approach is not the core of her fourth amendment jurisprudence. What is consistent about her approach is the great weight she gives to state interests, especially to the demands of effectively administering a criminal justice system, and her corresponding willingness to subordinate, at least in part, individual claims of privacy and possessory rights. ${ }^{229}$

2. Double Jeopardy. Justice O'Connor's treatment of the double jeopardy clause of the fifth amendment is marked by similar emphases and yields similar conclusions. A good example is Thigpen $v$. Roberts. ${ }^{230}$ In Thigpen, the defendant had lost control of his car and collided with a truck, killing a person in the truck. He was convicted of four motor-vehicle misdemeanors, all of which he appealed under the state's two-tier system for trying traffic offenses; under this system the defendant's initial conviction for the misdemeanor charges (in a justice-of-the-peace court) would be rendered entirely without effect on appeal, where the defendant was entitled to a wholly new trial. While this appeal was pending, the defendant was separately indicted and convicted on a manslaughter charge arising out of the same accident. The manslaughter conviction was later reversed by a federal court under the double jeopardy clause. The Supreme Court, through Justice White, affirmed that reversal on other grounds, without reaching the double jeopardy issue. ${ }^{231}$

Writing in dissent, Justice O'Connor argued that the Court should have addressed the double jeopardy question and overturned the lower court's decision. ${ }^{232}$ Her view would have substantially narrowed the scope of the clause. She argued that no double jeopardy problem was presented here because "jeopardy does not

120 Cf. United States v. Karo, 104 S. Ct. 3296, 3307 (1984) (O'Connor, J., concurring) (allowing certain uses of electronic beepers as aids to law enforcement).

230 104 S. Ct. 2916 (1984).

2si Id. at 2918-19. The Court found that the defendant's prosecution for manslaughter, which was initiated after he asserted his right to appeal his misdemeanor convictions, raised a presumption of prosecutorial vindictiveness that violated the defendant's due process rights. Id. at 2918-20.

${ }^{231}$ But cf. Justices of Boston Mun. Court v. Lydon, 104 S. Ct. 1805, 1828-30 (1984) ( $O$ 'Connor, J., dissenting) (habeas petition should be denied without reaching double jeopardy issue because petitioner was not in "custody"). 
attach in the first tier of a 'two-tier' criminal trial." ${ }^{233}$ In this instance, the defendant had not even paid the fine imposed for his original conviction.

This is surely dispositive evidence that [the defendant] was never in "jeopardy" at his first-tier trial. Though he was tried, convicted, and sentenced at that trial, he effortlessly erased his conviction and suffered no punishment whatsoever for the offense of reckless driving. If [the defendant] was never in jeopardy at his first-tier trial, the second trial could in no circumstance violate [his] constitutional right to avoid being placed twice in jeopardy for the same offense. ${ }^{234}$

In other words, constitutional problems did not arise merely because the defendant would be subjected to more than one trial. The defendant must show something more, must be placed at some substantial risk, in order to be entitled to the protection of the double jeopardy clause.

Justice O'Connor's opinion for a divided Court in Tibbs $v$. Florida ${ }^{238}$ also took a restrictive view of double jeopardy protections. The defendant's original conviction on charges of rape and murder was set aside by the state supreme court for being against the weight of the evidence, and the case was remanded for a new trial on the same charges. The issue posed to the Supreme Court was whether a second trial would place the defendant in double jeopardy.

The Court ruled that the second trial was permissible. Justice O'Connor's opinion for the Court distinguished a reversal of a conviction based on the weight of the evidence from a reversal of a conviction based on insufficient evidence, which prior Court decisions had established would preclude a new trial under the double jeopardy clause. ${ }^{236}$ The difference, in her view, was that the reversal here "does not mean that acquittal was the only proper verdict. Instead, the appellate court sits as a 'thirteenth juror' and disagrees with the jury's resolution of the conflicting testimony." This difference was significant for two reasons. First, because this reversal was unlike an acquittal, it did not merit the special importance that the double jeopardy clause attaches to acquittals. ${ }^{238} \mathrm{Sec}$ -

\footnotetext{
23s Thigpen, $104 \mathrm{~S}$. Ct. at 2923 (O'Connor, J., dissenting).

234 Id. at 2924.

235 457 U.S. 31 (1982).

2s8 See Greene v. Massey, 437 U.S. 19 (1978); Burks v. United States, 437 U.S. 1 (1978).

237 457 U.S. at 42.

2ss Id. at $41-42$ \& n.15.
} 
ond, the guilty verdict and reversal indicated that the state not only had persuaded the jury to convict, but that it had presented what the reviewing court agreed was sufficient evidence to support that conviction. "The reversal simply affords the defendant a second opportunity to seek a favorable judgment"239 and creates no double jeopardy problems. ${ }^{240}$

In Tibbs, as in Thigpen, Justice O'Connor defined the scope of the double jeopardy clause according to a narrow view of its purpose. In Tibbs, she ruled that a second trial would be permitted where the first trial had not resulted in an outcome closely equivalent to an acquittal. In Thigpen, she argued that a first trial should not bar a second trial unless it had put the defendant at some substantial risk. In neither case would she have spared the defendant the trauma and potential harassment of a second trial. ${ }^{211}$ Thus, her approach would relax constitutional obstacles to the prosecution of suspected criminals.

3. The Exclusionary Rule. Justice O'Connor has also supported law-enforcement interests by restricting the occasions on which evidence will be excluded from use at trial. Although she has adopted different justifications for this approach in different settings, all her opinions attempt to narrow the scope of the exclu-

23s Id. at 43.

240 Justice White's dissent emphatically rejected the Court's analysis. He pointed out that if the retrial involved only the same evidence that was presented in the first trial, then a reviewing court would again be obliged to set aside a conviction. "Thus, the only point of any second trial in this case is to allow the State to present additional evidence to bolster its case. If it does not have such evidence, reprosecution can serve no purpose other than harassment." Id. at 48 (White, J., dissenting). Permitting a second trial under these circumstances would directly offend "the deeply ingrained principle that "the State with all its resources and power should not be allowed to make repeated attempts to convict an individual for an alleged offense." "Id. at 50-51 (quoting Green v. United States, 355 U.S. 184, 187 (1957)). Justice White also noted that the Court's ruling might allow lower courts to evade prior decisions barring retrial after the reversal of a conviction based on insufficient evidence. In his view, the distinction between reversals based on the weight of the evidence and those based on insufficient evidence is often slight or even nonexistent. Thus, lower courts would be able to permit a retrial merely by portraying the reversal as one based on the weight of the evidence. 457 U.S. at 51 (White, J., dissenting). Justice O'Connor was more sanguine about the ability of judges to distinguish the two situations. Id. at $43 \& \mathrm{n} .18,45$ (majority opinion).

241 This purpose of the double jeopardy clause is explained in Green v. United States, 355 U.S. 184, 187-88 (1957):

The underlying idea, one that is deeply ingrained in at least the Anglo-American system of jurisprudence, is that the State with all its resources and power should not be allowed to make repeated attempts to convict an individual for an alleged offense, thereby subjecting him to embarrassment, expense and ordeal and compelling him to live in a continuing state of anxiety and insecurity, as well as enhancing the possibility that even though innocent he may be found guilty. 
sionary rule.

In Taylor $v$. Alabama, ${ }^{242}$ the Court ruled that the defendant's confession, obtained through interrogation following his illegal arrest, should not have been admitted into evidence. The arrest was illegal because it had been made without probable cause. Describing the case as "a virtual replica" of two prior Supreme Court decisions, Justice Marshall's opinion for the Court stated that the crucial issue was whether intervening events had broken the causal connection between the illegal arrest and the confession "so that the confession is 'sufficiently an act of free will to purge the primary taint." "243 $\mathrm{He}$ found nothing in these facts to break the causal connection between arrest and confession, although the defendant had been allowed a very brief meeting with his girlfriend, and Miranda warnings had been given three times. He stressed that "[i]f Miranda warnings were viewed as a talisman that cured all Fourth Amendment violations, then the constitutional guarantee against unlawful searches and seizures would be reduced to a mere 'form of words.' "244.

Justice O'Connor dissented. Agreeing with the Court's identification of the central issue, she argued that the causal connection between arrest and conviction had been broken. She placed greater weight on the repeated Miranda warnings than did the Court; she also noted that the girlfriend's visit was permitted at the defendant's request, that no intimidating police misconduct had occurred, and that the defendant spent much of the time between his arrest and his confession by himself. Thus, she would not have excluded the confession. ${ }^{245}$ Although Taylor may be viewed as turning simply on a disagreement about particular facts, in two other cases Justice O'Connor tried to carve out sizable exceptions to the exclusionary rule.

In Immigration \& Naturalization Service v. Lopez-Mendoza, ${ }^{246}$ the Court considered whether the exclusionary rule applied in the context of a civil deportation hearing. The defendant, a Mexican citizen, was arrested illegally at his place of employment by government agents. While in the custody of the agents, he confessed to having entered the United States illegally. In a subsequent deportation hearing, he sought to have this confession sup-

\footnotetext{
242457 U.S. 687 (1982).

${ }^{243}$ Id. at 690 (quoting Brown v. Illinois, 422 U.S. 590, 602 (1975)).

${ }^{244} 457$ U.S. at 690 (quoting Brown v. Illinois, 422 U.S. 590, 603 (1975)).

245457 U.S. at 699-701 (O'Connor, J., dissenting).

248 104 S. Ct: 3479 (1984).
} 
pressed as the fruit of an illegal arrest. His request was denied, and a deportation order was entered. ${ }^{247}$

Justice O'Connor's opinion for the Court held that the exclusionary rule did not apply in a civil deportation hearing. Beginning from the fact that deportation hearings require fewer protections for the individual than do criminal hearings, ${ }^{248}$ she went on to conclude that in this setting the social costs of the exclusionary rule outweighed its ability to deter future unlawful police conduct. In reaching that conclusion, she stressed several factors that she thought lessened the rule's deterrence value in this context: the nature of other readily available evidence; the rarity with which hearings are demanded; the existence of agency provisions for deterring fourth amendment violations; and the availability of alternative remedies. ${ }^{249}$ On the other side of the balance, the social costs of compelling the release of those who may be unlawfully present in the country, along with the burdens that the rule would impose on the agency's deliberately streamlined procedures, militated against imposition of the rule..$^{250}$

Justice O'Connor thus found grounds for dispensing with the rule in the narrow purpose for its creation. The purpose of exclusion is deterrence; the deterrence value in the deportation context is low; therefore, the exclusionary rule should not be applied in the deportation context. ${ }^{201}$

Similarly, in New York v. Quarles, ${ }^{252}$ Justice O'Connor suggested a potentially much larger exception to the exclusionary rule, this time as it applied to Miranda violations. As described earlier, ${ }^{253}$ the Court held in Quarles that the Miranda requirements were subject to an exception where police officers asked the suspect questions "reasonably prompted by a concern for the public safety."254 In a separate opinion, Justice O'Connor rejected the Court's approach as an unjustified departure from precedent, but

247 Id. at 3482-83.

248 Id. at 3484. For example, she noted that deportation hearings may proceed in the respondent's absence and that the burdens of proof in a deportation hearing may differ from those applied in criminal trials.

249 Id. at 3486-88. Cf. United States v. Karo, 104 S. Ct. 3296, 3307 (1984) (O’Connor, J., concurring) (strengthening standing requirements for invocation of the exclusionary rule).

${ }^{280}$ Lopez-Mendoza, $104 \mathrm{~S}$. Ct. at 3488-90.

281 The account here emphasizes the opinion's discussion of deterrence, but Justice O'Connor also made much of the social costs of the rule: her reasoning incorporated both factors.

252104 S. Ct. 2626 (1984).

25s See supra notes $11-16$ and accompanying text.

254104 S. Ct. at 2632. 
argued that a Miranda violation did not compel the suppression of non-testimonial evidence. She was fully aware that this position

will reduce the incentives to enforce the Miranda code. But that fact simply begs the question of how much enforcement is appropriate. There are some situations ... in which the societal cost of administering the Miranda warnings is very high indeed. The Miranda decision quite practically does not express any societal interest in having those warnings administered for their own sake. Rather, the warnings and waiver are only required to ensure that "testimony" used against the accused at trial is voluntarily given. Therefore, if the testimonial aspects of the accused's custodial communications are suppressed, the failure to administer the Miranda warnings should cease to be of concern. ${ }^{255}$

This passage is a striking example of Justice O'Connor's approach to this area of the law and is consistent with her approach in Lopez-Mendoza. First, she found that the scope of the exclusionary rule is confined by its underlying purpose, which she took to be deterrence of unlawful government conduct. ${ }^{256}$ Second, she identified the social costs of the rule: it hampered law enforcement, and at times it could also threaten the public safety. Third, she balanced the protection that the rule would afford against the harm done to society's interests, and she did so in a manner that greatly restricted the scope of the rule and correspondingly aided government's ability to enforce the law.

B. Limits on the Authority to Govern: The First Amendment and the Equal Protection Clause

Justice O'Connor's discussions of the double jeopardy clause and the exclusionary rule show that she often seeks to avoid broad interpretations of constitutional protections of individual rights by limiting them in light of a narrow view of their underlying purposes. In her few statements to date about rights under the first

${ }^{205}$ Id. at 2638-39 (O'Connor, J., concurring in part and dissenting in part) (emphasis in original) (footnote and citation omitted).

${ }^{258}$ Actually, deterrence is not the only purpose that has been suggested for the exclusionary rule. Especially in earlier cases, the "imperative of judicial integrity" was set forth as a justification for a court's refusal to contaminate its processes with illegally obtained evidence. See, e.g., Elkins v. United States, 364 U.S. 206, 222-23 (1960). But subsequent cases have relied more heavily on the deterrence rationale. See, e.g., Stone v. Powell, 428 U.S. 465, 484-86 (1976) (stating that deterrence has overtaken judicial integrity as the "primary justification" for the exclusionary rule). 
amendment and the equal protection clause, her approach seems to be much less uniform. In some instances, she seems to approach the constitutional provisions with an eye toward the framers' narrow purposes. But in other instances, she pays little attention to the purposes of the constitutional provision; in these instances, she tends to uphold the challenged government action. As the direction of Justice O'Connor's views in these areas remains uncertain, it is difficult to draw any definite conclusions about this aspect of her jurisprudence.

1. First Amendment Rights. Justice O'Connor's first amendment jurisprudence has not yet taken a definite shape. Nonetheless, her few opinions in this area do reflect certain themes that are consistent with the general thrust of her approach in other areas.

One case that exemplifies her attention to purposes is Lynch $v$. Donnelly, ${ }^{257}$ the celebrated decision in which the Court ruled that the city of Pawtucket, Rhode Island, did not violate the establishment clause of the first amendment by including a Nativity scene in its annual public Christmas display. Both the four-Justice plurality opinion and the four-Justice dissent applied the threeprong test for establishment clause violations that the Court had fashioned earlier in Lemon $v$. Kurtzman, ${ }^{258}$ although the plurality expressly declined to be confined strictly to this test. ${ }^{269}$ Under Lemon, state action is valid under the establishment clause only if the action has a secular purpose, its primary effect is neither to advance nor inhibit religion, and it creates no excessive entanglement of government with religion. ${ }^{260}$ The disagreement between the plurality and the dissenters in Lynch was over how that test should be applied to these particular facts.

In a separate concurrence, Justice O'Connor proposed "a clarification of our Establishment Clause doctrine."261 Her approach began with the purposes that she saw underlying the clause:

The Establishment Clause prohibits government from making adherence to a religion relevant in any way to a person's standing in the political community. Government can run afoul of that prohibition in two principal ways. One is excessive entanglement with religious institutions. . . . The second and more direct infringement is government endorsement

\footnotetext{
267104 S. Ct. 1355 (1984).

288 403 U.S. 602 (1971).

265 $104 \mathrm{~S}$. Ct. at 1362 (plurality opinion).

280 Lemon, 403 U.S. at 612-13.

$261104 \mathrm{~S}$. Ct. at 1366 (O'Connor, J., concurring).
} 
or disapproval of religion. ${ }^{262}$

Agreeing with the plurality that no entanglement problems were posed here, she analyzed the endorsement issue in greater detail by "examin[ing] both what Pawtucket intended to communicate in displaying the crèche and what message the City's display actually conveyed."263 She then concluded that no endorsement could be found on these facts. The city's purpose was merely to celebrate a public holiday through its traditional symbols, not to endorse Christianity. Although the scene probably had the effect of advancing religion, "the overall holiday setting changes what viewers may fairly understand to be the purpose of the display-as a typical museum setting, though not neutralizing the religious content of a religious painting, negates any message of endorsement of that content."264 Thus, no violation of the establishment clause had occurred.

Justice O'Connor's analysis in Lynch altered the second prong of the Lemon test. The only effect of state action that she would have found impermissible was the communication of an endorsement or disapproval of religion, not simply any effect that advances or inhibits religion. State action could be permitted to advance or inhibit religion (indeed this might even be its principal effect) so long as the reviewing court could not conclude that the action actually conveyed a message endorsing or disapproving religion. In short, she had defined the purposes of the establishment clause in a manner that limited its scope. ${ }^{265}$

${ }^{262}$ Id. (citation omitted). One of the most striking aspects of her opinion, however, is that it offered no justifications of any kind to support her understanding of the purposes of the clause. This omission is especially surprising in light of the fact that her view of the purposes of the clause differed from the brief accounts offered by the plurality, id. at 135859, and by Justice Brennan, id. at 1372 (Brennan, J., dissenting). For examples of more careful analysis, see Minneapolis Star \& Tribune Co. v. Minnesota Comm'r of Revenue, 460 U.S. 575, 583-85 (1983) (O'Connor, J.) (arguing that differential taxation of the press was a serious concern for the framers); Zobel v. Williams, 457 U.S. 55, 78-80 (1982) (O'Connor, J., concurring) (showing that free travel among the states was originally tied to the privileges and immunities clause).

${ }^{263} 104 \mathrm{~S}$. Ct. at 1367 (O'Connor, J., concurring).

204 Id. at 1369 (emphasis added).

${ }^{285}$ It is not entirely clear how much her position would alter the second prong of the Lemon test in practice. In the more significant cases, the outcome would be the same because it would be difficult not to find "endorsement or disapproval" where a government measure's principal effect was to advance or inhibit religion significantly. The real difference would arise where a measure's principal effect might be to advance or inhibit religion, but not to the extent that government endorsement or disapproval could be inferred. In Justice O'Connor's view, Pawtucket's Nativity scene was a minor activity akin to legislative prayers, which serve "the legitimate secular purposes of solemnizing public occasions, expressing confidence in the future, and encouraging the recognition of what is worthy of appreciation 
Again, in Minneapolis Star \& Tribune Co. v. Minnesota Commissioner of Revenue, ${ }^{268}$ Justice O'Connor's majority opinion focused on the purposes of the first amendment, but on this occasion the challenged statute was invalidated. Minnesota had imposed a special use tax, in lieu of the regular state sales tax, on certain paper and ink products used to produce periodical publications. The tax was accompanied by various exemptions so that the effect was to burden only a handful of publishers. In fact, the complaining newspaper publisher typically paid two-thirds of the total revenues raised by the tax. ${ }^{267}$ The Court struck down the tax as a violation of freedom of the press.

The keystone of the Court's opinion was its attention to the purposes underlying the first amendment's protection of the press. Justice O'Connor candidly noted that this was not the usual judicial approach to first amendment problems because there is little direct evidence about the amendment's purposes. "But when we do have evidence that a particular law would have offended the Framers, we have not hesitated to invalidate it on that ground alone."26s She then found, from the debates over ratification of the Bill of Rights, considerable evidence that differential taxation of the press was one of the specific evils that the first amendment was intended to prevent. ${ }^{268}$ The next step was to "balance the burden implicit in singling out the press against the interest asserted by the State. ... [T] he regulation can survive only if the governmental interest outweighs the burden and cannot be achieved by means that do not infringe First Amendment rights as significantly."270 Here the state had not adequately justified the design of the tax: "[W]e think that recognizing a power in the State not only to single out the press but also to tailor the tax so that it singles out a few members of the press presents such a potential for abuse that no interest suggested by Minnesota can justify the scheme."271

Justice Rehnquist's dissent vehemently disagreed with the majority's analysis. He analyzed the economic effects of the tax in an attempt to show that this use tax, which applied to publishers in lieu of the state sales tax, actually left even the complaining pub-

in society." Id. at 1369. Nonetheless, these supposedly inconsequential cases could well encompass most of the hard cases.

200460 U.S. 575 (1983).

207 Id. at 578-79. The taxing statute was MinN. STAT. § 297A.02 (1982).

208460 U.S. at 583 n.6.

260 Id. at $583-85$.

270 Id. at 585 n.7.

271 Id. at 592. 
lisher better off than if the tax treatment of the press had been more even-handed. ${ }^{272}$ Thus, in his view, the state had not in any way infringed on freedom of the press. In addition to disputing the dissent's theoretical conclusions, Justice O'Connor emphatically rejected the suggestion that courts should embark on such investigations in the first amendment context. "When delicate and cherished First Amendment rights are at stake, . . . the constitutional tolerance for error diminishes dramatically, and the risk increases that courts will prove unable to apply accurately the more finely tuned standards." "273

Both Lynch and Minneapolis Star reflect themes that also run through Justice O'Connor's fourth amendment jurisprudence: the starting point for analysis is a definition of the underlying purpose of the clause in question. But in two other opinions in the first amendment area, Justice O'Connor failed to attend closely to the purposes of the constitutional provision; instead, she merely accepted the competing interests identified by other Justices and argued that the Court had struck a balance that was too protective of the individual's rights.

The more problematic of these examples of Justice O'Connor's first amendment jurisprudence arose in Brown v. Socialist Workers '74 Campaign Committee, ${ }^{274}$ in which the small Socialist Workers Party challenged an Ohio statute that required candidates for political office to disclose each contributor and recipient of campaign funds. ${ }^{275}$ The Court examined the statute in light of a privacy right inferred from the first amendment-the "right to privacy in one's political associations and beliefs."276 The Court held that no compelling state interests justified mandatory disclosure by this minor political party and found the statute unconstitutional as applied in this instance. ${ }^{277}$

${ }^{272}$ Id. at 597-98 (Rehnquist, J., dissenting). He compared the amounts raised by the use tax with the amounts that would have been raised by applying the sales tax, assuming the same price and gross sales. Justice O'Connor questioned these assumptions. Id. at 590 n.14 (majority opinion).

${ }^{275}$ Id. at 589 n.12. This statement was directed against Justice White's separate opinion, in which he concurred in the result but declined to join the Court's skepticism about inquiries into the economic effect of particular taxes. See id. at 594-96 (White, J., concurring).

274459 U.S. 87 (1982).

${ }_{275}$ OHIo Rev. Code ANN. $\S 3517.01$ to .99 (Baldwin 1972 \& Supp. 1981).

278459 U.S. at 91.

${ }^{277}$ Id. at 92-98, 98-102. The Court relied heavily on its analysis in Buckley v. Valeo, 424 U.S. 1 (1976), in concluding that the government interests in information disclosure were attenuated when applied to minor parties, especially when evidence suggested that the minor party had been subjected to harassment in the past. 
Writing in partial dissent, Justice O'Connor took issue with the breadth of the Court's holding. She agreed with the Court that the statute was unconstitutional as applied to require disclosure of the minor party's contributors, but she would have upheld compulsory disclosure of the recipients of campaign expenditures. ${ }^{278}$ She accepted the Court's identification of the competing governmental and individual interests, but disagreed with the balance struck by the majority. In her view, the state interests in preventing improper electoral conduct remained strong when the statute was applied to minor parties. ${ }^{279}$ She also argued that disclosure threatened the associational rights of recipients less than it threatened the rights of contributors: unlike contributors, who express their political views by the very act of contribution, recipients tend to be either ordinary businesses or active campaigners, and in neither instance is the privacy of their political beliefs likely to be threatened by disclosure. ${ }^{280}$

The difficulty with this approach is that it may underemphasize the nature of the speech at stake in Brown. The threat here was to political speech, which is essential to the preservation of healthy democratic institutions, and which is undeniably the kind of speech that the first amendment was primarily intended to protect. Yet Justice O'Connor eschewed any reference to the underlying purpose of the first amendment.

Similarly, in Roberts $v$. United States Jaycees, ${ }^{281}$ she disagreed with the Court's implementation of the applicable standard without tying her approach to first amendment purposes. In Roberts, the Court held that a Minnesota Human Rights Department order that the Jaycees admit women to its state chapters did not abridge any associational rights possessed by Jaycee members. In particular, the Court held that the state's compelling interest in eradicating gender discrimination justified any impact that the order might have on the members' freedom of expressive association. ${ }^{282}$

Although concurring in most of the Court's opinion, Justice

278459 U.S. at 107 ( $\mathrm{O}^{\prime}$ Connor, J., concurring in part and dissenting in part).

278 More specifically, she argued that minor parties were not less likely to engage in corrupt practices merely because they were unlikely to win the election and that any resulting deflection of votes could still determine the outcome of the election among the other candidates. Id. at 109-10 \& nn.4-6. The Court's opinion expressly denied the importance of these points. Id. at $95 \&$ n. 11 .

${ }^{280}$ Id. at $110-12$ (O'Connor, J., concurring in part and dissenting in part).

281104 S. Ct. 3244 (1984).

${ }^{282}$ Id. at 3252-55. 
O'Connor disagreed with this statement of the test for judging infringement of expressive association. First, she feared that requiring a showing of a compelling state interest might allow some commercial associations to use the first amendment as a shield to gain protection for discrimination by occasionally engaging in expressive activities. ${ }^{283}$ Second, the Court's hasty application of the compelling-state-interest test neglected to establish at the outset that the Jaycees merited the strong protections afforded to expressive associations. She then offered her own standard:

In my view, an association should be characterized as commercial, and therefore subject to rationally related state regulation of its membership and other associational activities, when, and only when, the association's activities are not predominantly of the type protected by the First Amendment. It is only when the association is predominantly engaged in protected expression that state regulation of its membership will necessarily affect, change, dilute, or silence one collective voice that would otherwise be heard. An association must choose its market. Once it enters the marketplace of commerce in any substantial degree it loses the complete control over its membership that it would otherwise enjoy if it confined its affairs to the marketplace of ideas. ${ }^{284}$

She recognized that assessing "predominance" might be difficult in some instances. But she had little difficulty concluding that the Jaycees were predominantly a commercial association and thus could be subjected to rational state regulation. ${ }^{285}$ The larger significance of her test, however, lay in its broad rejection of first amendment protection for the associational rights of organizations that undertake any substantial amount of commercial activity. ${ }^{\mathbf{2 8 8}}$

${ }^{283}$ Id. at 3257-58 (O'Connor, J., concurring). She was especially concerned about how the Court would rule in a situation where it found that the admission of women to an organization, especially to a highly discriminatory organization, "would affect the content of the organization's message." Id. at 3258. Her emphasis on defending the state's power "to pursue the profoundly important goal of ensuring nondiscriminatory access to commercial opportunities in our society," id. at 3257 , bears comparison with her majority opinion in Mississippi Univ. for Women v. Hogan, 458 U.S. 718 (1982), which ruled that the same "profoundly important goal" might also justify serious restraints on state power. For a discussion of Hogan, see infra notes 287-92 and accompanying text.

${ }^{284} 104 \mathrm{~S}$. Ct. at 3259 (O'Connor, J., concurring).

285 Id. at 3261 .

${ }^{286}$ Justice O'Connor has not yet expressed specific views on the protections afforded to various forms of speech, but in New York v. Ferber, 458 U.S. 747 (1982), where the Court upheld a statute outlawing child pornography, her brief concurring opinion suggested that "the Constitution might in fact permit [states] to ban knowing distribution of works depict- 
2. Equal Protection. Justice O'Connor's one major opinion in the equal protection area sheds little light on her approach to this constitutional provision. Writing for a bare majority of the Court, Justice O'Connor ruled in Mississippi University for Women $v$. $\mathrm{Hogan}^{\mathbf{2 8 7}}$ that the single-sex admissions policy of a state-run nursing school, which vexcluded men, violated the equal protection clause. Her legal analysis was straightforward. Adhering closely to the language of prior cases, she decided that the proper standard for reviewing this admissions policy, which openly discriminated against individuals on the basis of gender, was whether the state's objective was "legitimate and important," and whether a "direct, substantial relationship between objective and means is present"; this standard is meant to ensure "that the validity of a classification is determined through reasoned analysis rather than through the mechanical application of traditional, often inaccurate, assumptions about the proper roles of men and women." 288 She found that the state's policy failed to meet either prong of this test.

The alleged state objective was to compensate for past discrimination against women. Justice O'Connor undertook a "searching analysis" of this justification ${ }^{289}$ and found it to be unpersuasive. Mississippi had made no showing that women lacked opportunities for training in the field of nursing; on the contrary, women were already earning practically all the nursing degrees conferred, both within the state and nationwide. Thus, not only did this single-sex admissions policy not benefit women by compensating for any past discrimination, but it even "tend[ed] to perpetuate the stereotyped view of nursing as an exclusively woman's job."280

Justice O'Connor also concluded that this restrictive admissions policy bore no direct or substantial relationship to the state's proposed objective. Men were allowed to audit and to participate fully in the nursing school's classes, and the trial record showed that excluding men from full admission did not advance any particular educational goals. Thus, even if the discriminatory policy

ing minors engaged in explicit sexual conduct, regardless of the social value of the depictions," id. at 774 (O'Connor, J., concurring). This statement suggests that she may adhere to a fairly narrow view of the kinds of speech that are protected by the first amendment.

287458 U.S. 718 (1982).

28s Id. at 725-26.

289 Id. at 728 .

290 Id. at 729 . According to the Court, women were earning over $90 \%$ of all baccalaureate nursing degrees, both within the state and across the country. Id. 
did benefit women, that benefit was indefensible because it did not contribute to the overall goals of this program. ${ }^{291}$

It would be improvident to infer much about Justice O'Connor's views of the equal protection clause from this one case. Nevertheless, Hogan suggests that she may have a special concern for protection of individuals against state action in the gender discrimination context. One could interpret her opinion in Roberts $v$. United States Jaycees ${ }^{292}$ as a reflection of this same special concern, though the inference would be weaker in that case. Taken together, Hogan and Roberts might be the early work of a Justice committed to furthering equality of the sexes, even when that commitment does not mesh easily with other aspects of her jurisprudence.

\section{ConCLUSION}

The emerging jurisprudence of Justice O'Connor is marked by its general consistency over a broad range of subjects. The dominant themes are respect for the powers and responsibilities exercised by the political branches of the government and a corre-

${ }^{291}$ Id. at 730-31. Justice Powell's dissent sheds interesting light on a federalism approach that Justice $O^{\prime}$ Connor could have employed to reach a different result. He argued that the Court's decision would produce an unnecessarily broad conformity by rejecting the state's efforts "to provide women with a traditionally popular and respected choice of educational environment." Id. at 735 (Powell, J., dissenting). But she rejected the view that the state's goal of preserving diversity in educational environments could save this discriminatory policy. Id. at $731 \mathrm{n} .17$ (majority opinion). Her refusal to countenance this argument suggests a view that the equal protection clause cannot be overridden by the assertion of directly incompatible state interests. In light of her usual views on federalism, see supra notes 138-205 and accompanying text, this would indicate a fairly firm view of equal protection rights, at least in the gender context.

${ }^{292} 104 \mathrm{~S}$. Ct. 3244 (1984) (discussed supra notes 281-86 and accompanying text); $c f$. Guardians Ass'n v. Civil Serv. Comm'n, 103 S. Ct. 3221, 3237-38 (1983) (O'Connor, J., concurring) (construing Title VI to redress nothing more than purposeful discrimination, but suggesting that she would have construed the statute differently had a majority of the Court not already ruled on the issue in Regents of the Univ. of Cal. v. Bakke, 438 U.S. 265 (1978)). Moreover, in Mills v. Habluetzel, 456 U.S. 91 (1982), Justice O'Connor also took a generous view of equal protection rights. Although the case did not involve a gender-based classification, the concerns were not entirely dissimilar. The Court used the equal protection clause to invalidate a Texas statute barring paternity suits brought on behalf of illegitimate children more than one year after their birth. Id. at 101. In a separate opinion, Justice O'Connor called into question the state's new four-year limitations period on these actions, enacted after this suit had been brought. She noted that this cause of action was one of very few Texas actions not tolled during the plaintiff's minority, id. at 104 ( $0^{\prime}$ Connor, J., concurring), and that the risk "that the child will find himself without financial support from his natural father seems as likely throughout his minority as during the first year of his life," id. at 106. Thus, she argued that the Court's opinion had not prejudged the constitutionality of longer alternative limitation periods for paternity actions. 
sponding concern that courts should be cautious in obstructing the power to govern. In ordinary parlance, these positions represent a fairly "conservative" jurisprudence. The consistency of Justice O'Connor's approach could thus help to sharpen the debate over the propriety of this approach, a debate that will undoubtedly influence future trends in what is now an ideologically divided Court.

One of Justice O'Connor's primary goals is to fashion a more modest role for the courts. Firmly believing in the governmental system of separated powers, she seems unwilling to have the judiciary seek to serve as the ultimate authority among the coordinate branches. ${ }^{283}$ Indeed, she is extremely deferential to executive and legislative actions, apparently on the ground that the judicial branch alone lacks a direct political tie to the sovereign power of the people. Both views are defensible but are also very much open to debate. The former position perhaps oversimplifies the nature of the judicial role in the American constitutional system: to the extent that a vigorous judiciary is necessary to preserve a proper balance among the branches of government, strong mediating powers are in order for the courts. ${ }^{294}$. The latter position may also rest on a mistaken view of American politics, which is not simply a democratic politics, but democracy tempered with a strong suspicion of concentrated power. American government combines the principle of majority rule with protection for minority rights; democracy is restrained by the rule of law, and the courts are an important guardian against the dangers of majority tyranny that were so feared by the nation's founders. Nonetheless, on the side of Justice O'Connor's approach is the simple but cogent observation that the judiciary may at some point simply go too far in asserting its expansive powers, and the specter of majority tyranny may give way to the reality of judicial tyranny.

Justice O'Connor's view of federalism also raises significant questions about the system of government. Her view rests on what she sees as the logical implications of statehood: the federal and state governments share in a partnership, with each drawing its legitimacy from the fundamental sovereign power that resides in the people. Although the federal government enjoys a superior sta-

293 See, e.g., Allen v. Wright, 104 S. Ct. 3315 (1984) (discussed supra notes 84-105 and accompanying text); City of Akron v. Akron Center for Reproductive Health, Inc., 462 U.S. 416, 465 (1983) (O'Connor, J., dissenting) (discussed supra notes 31-48 and accompanying text); ASARCO Inc. v. Idaho State Tax Comm'n, 458 U.S. 307, 331 (1982) (O'Connor, J., dissenting) (discussed supra notes 117-25 and accompanying text).

204 See, e.g., The Federalist Nos. 78 \& 80 (A. Hamilton); Levi, The Sovereignty of the Courts, 50 U. ChI. L. Rev. 679 passim (1983). 
tus in this partnership, its powers are at least subject to minimal procedural restraints that protect the mechanisms of state government against overly intrusive uses of federal powers. ${ }^{295}$ The logic of this view is sound, but it is open to at least two practical criticisms. First, it tends to play down the fundamental alteration in the federal system brought about by the Civil War and the subsequent constitutional amendments. ${ }^{296}$ Second, because her approach so far has been almost purely procedural, it is inadequate to restore any real political power to the states. Indeed, by stifling "intrusive" efforts by the federal government to design measures that will involve the states in "cooperative federalism," her approach might simply provoke more direct assertions of broad federal powers.

Justice O'Connor's positions on certain other substantive constitutional issues are probably her most controversial. She often takes a limited view of constitutionally protected individual rights: she tends to interpret these protections narrowly, according to a strict view of their original purposes, and thus seeks to bolster democratic power against the impediments raised by extensive judicial activity. Although on occasion she has come down on the side of broad first amendment and equal protection rights, her usual approach is deferential to government interests, especially the interest in effective law enforcement. ${ }^{297}$ But one may doubt whether it is appropriate to confine constitutional provisions within the narrow purposes that the framers may have had in mind. Perhaps these provisions should be interpreted generously because they reflect important values intended to guide the American experiment in self-government in unforeseen circumstances. And one important "state interest" is maintaining a government, of which the federal judiciary is a critical element, that diligently seeks to limit its own power by defending these values.

\footnotetext{
295 See, e.g., Michigan v. Long, 103 S. Ct. 3469 (1983) (discussed supra notes 193-205 and accompanying text); Federal Energy Regulatory Comm'n v. Mississippi, 456 U.S. 742, 775 (1982) (O'Connor, J., dissenting) (discussed supra notes 141-55 and accompanying text).

${ }^{298}$ See, e.g., Fitzpatrick v. Bitzer, 427 U.S. 445, 453-56 (1976). Alexander Hamilton pointed out that "an augmentation of federal authority without a diminution of State authority [or] sovereignty in the Union and complete independence in the members [represents] the political monster of an imperium in imperio." THE FEDERALIST No. 15, at 108 (A. Hamilton) (C. Rossiter ed. 1961). The most troublesome theoretical problem with federalism is to ascertain how much "diminution" of state authority is required.

${ }^{207}$ See, e.g., United States v. Place, 103 S. Ct. 2637 (1983) (discussed supra notes 21125 and accompanying text); City of Akron v. Akron Center for Reproductive Health, Inc., 462 U.S. 416, 465 (1983) (O'Connor, J., dissenting) (discussed supra notes 31-48 and accompanying text). But see Mississippi Univ. for Women v. Hogan, 458 U.S. 718 (1982) (discussed supra notes 287-92 and accompanying text).
} 
Finally, Justice O'Connor's opinions shed light on the paradox of "conservative" judicial activism. It is sometimes suggested that conservative Justices should not overturn established doctrines because they are obliged by their own philosophy to "conserve" the existing law. This view misconceives the nature of the judicial function. Justice O'Connor takes seriously the limitations imposed by ordinary notions of judicial restraint, but she has not looked for the answer to every important question in exact adherence to precedent. ${ }^{298}$ Much of the law, and especially constitutional law, which is built upon an authoritative document that "must be enormously ambiguous in its general provisions," 299 is simply too broad and fluid to doom a conservative judge to the status of a cipher.

Richard A. Cordray James T. Vradelis

298 See, e.g., New York v. Quarles, 104 S. Ct. 2626, 2634 (1984) (O'Connor, J., concurring in part and dissenting in part) (discussed supra notes 11-30 and accompanying text); United States v. Place, 103 S. Ct. 2637 (1983) (discussed supra notes 211-25 and accompanying text); Tibbs v. Florida, 457 U.S. 31 (1982) (discussed supra notes $235-41$ and accompanying text).

200 E. LEvi, supra note 28, at 59. See generally id. at 57-102 (examining the nature of constitutional interpretation). 